\title{
Sr isotope chemistry of contaminated Tertiary volcanic rocks from Disko, central West Greenland
}

\author{
A. K. PEDERSEN AND S. PEDERSEN
}

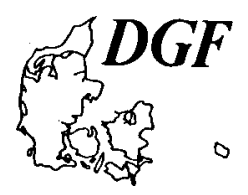

Pedersen, A. K. \& Pedersen, S.: Sr isotope chemistry of contaminated Tertiary volcanic rocks from Disko, central West Greenland. Bull. geol. Soc. Denmark, vol. 36, pp. 315-336. Copenhagen, December, 31th, 1987. https://doi.org/10.37570/bgsd-1988-36-12

\begin{abstract}
The $\mathrm{Sr}$ isotope chemistry of $\mathbf{2 6}$ samples of Tertiary volcanic rocks from the Vaigat and Maligât Formations on Disko are presented together with 5 samples of potential sedimentary contaminants from Disko and Nûgssuaq. The volcanic rocks include one primitive picrite, 11 basalts, 8 andesites, 4 dacites and 2 rhyolites. Except for two basalts, all the basaltic to rhyolitic rocks are distinctly enriched in radiogenic $\mathrm{Sr}$ and this together with petrographical observations is taken as evidence for reaction with crustal rocks. The widespread xenoliths and xenocrysts point to Mesozoic to early Tertiary sediments as the major contaminants and a shale and a sandstone composition have accordingly been chosen as model contaminants. Assimilation and Fractional Crystallization (AFC) calculations indicate that mafic silicates were the predominant fractionating phases in the contaminated members of the Vaigat Formation, whereas plagioclase crystallization and equilibration played a dominant role in the contaminated members of the Maligât Formation. The Kûgánguaq Member in the Vaigat Formation cannot be modelled with a shale contaminant, but easily with a sandstone contaminant, and one dacite sample in the Nordfjord Member of the Maligat Formation is best modelled with sandstone contaminant. For all the other rocks, there is evidence of a dominating shale contamination.

The most strongly contaminated rock on Disko analysed for Sr isotopes is a rhyolite from the Nordfjord Member, whereas another rhyolite showed evidence of less contamination but very extensive feldspar fractionation. None of the silica-enriched rocks on Disko appear to be formed by closed system fractionation of a basic uncontaminated magma.
\end{abstract}

A. K. Pedersen, Geologisk Museum, Øster Voldgade 5-7; S. Pedersen, Institut for Almen Geologi, Øster Voldgade 10, DK-1350, København K., June 26th, 1987.

\section{Introduction}

The Tertiary volcanic province of West Greenland is notable for its abundance of primitive picrites (Clarke, 1970; Clarke \& Pedersen, 1976) and for its volcanic rocks with native iron (Steenstrup, 1883; Bøggild, 1953 (review); Pedersen, 1981). The rocks with native iron are known from Disko and Nûgssuaq and are particularly widespread on Disko. These rocks occur as extrusives and intrusives and they are enriched in silica compared to the tholeiitic volcanic rocks which constitute by far the largest volumes of volcanics within the province. Their widespread xenoliths and xenocrysts of sedimentary origin attest to recurrent sediment-magma reactions throughout the voleanic history.

Isotope work by O'Nious \& Clarke (1972) and Carter et al. (1979) has demonstrated that the widespread Tertiary tholeiitic picritic to feldspar- phyric basalts in the Baffin Bay area are virtually uncontaminated by reaction with the Earth's crust and that they are characterized by low ${ }^{87} \mathrm{Sr} /{ }^{\beta 6} \mathrm{Sr}$ ratios. Sr isotope analyses on a few silicaenriched volcanic rock from Disko (Pedersen, $1981,1985 b$ ) have shown these rocks to be distinctly contaminated by radiogenic Sr.

This paper reports on $\mathrm{Sr}$ isotope analyses on a variety of silica-enriched volcanic rocks from Disko, ranging from olivine-porphyritic basalts to rhyolites, together with some xenoliths and unheated Mesozoic to Tertiary sediments. The work was carried out in order to investigate the extent of crustal contamination on the originally mantlederived magmas and we have assumed that the parents for the silica-enriched rocks were tholeiitic basalt derived from mantle reservoirs characterized by $10{ }^{87} \mathrm{Sr} /{ }^{86} \mathrm{Sr}$ ratios. As a first priority it was considered important to investigate if any of the silica-enriched volcanic rocks could be closed 


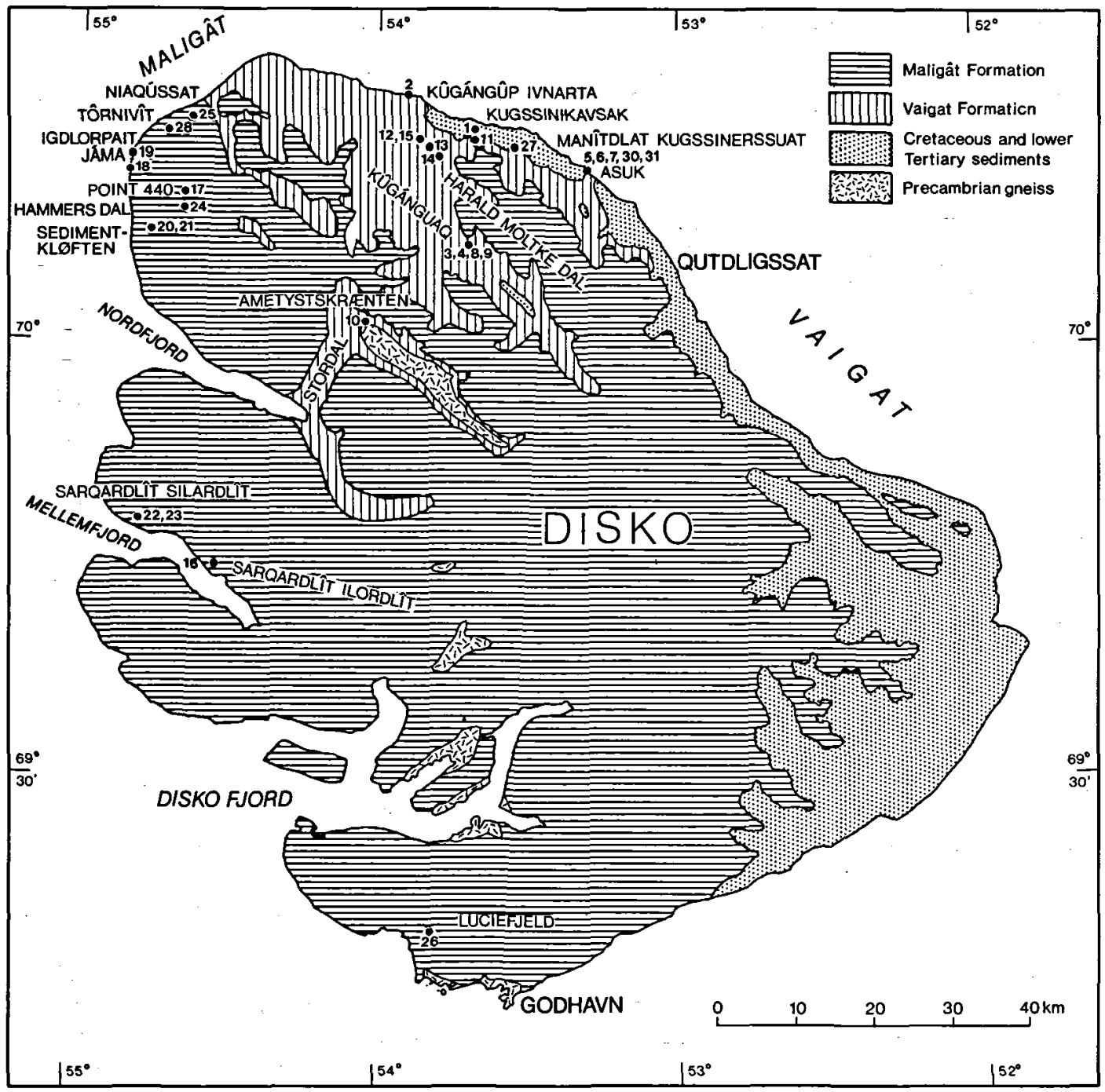

Fig. 1. The location of samples of analysed Tertiary volcanic rocks ( 1 to 26$)$ and sediments and sedimentary xenoliths ( 27 to 28 and 30 to 31 ) from Disko. For simplicity faults, Quaternary sediments and glaciers are omitted. Sample 29 is collected on Nûgssuaq.

system fractionates. For this reason sample selection covers a wide range of geological units and a wide diversity of rock types. Secondly, we have attempted to constrain the nature of the contaminants and to test a crude contamination model. Any quantitative analysis of the contamination processes operating on Disko must be based on a range of elements and isotopes obtained through a detailed sampling of one or a few selected volcanic systems and their xenoliths. We are fully aware of the limited scope of this paper. Before the isotope analyses are presented, the Tertiary volcanic rocks will be briefly described, and the silica-enriched rocks placed in a regional context.

\section{Geological setting}

The Tertiary volcanic rocks on Disko (fig. 1) have been divided into the Vaigat and Maligât Formations (Hald \& Pedersen, 1975). The Vaigat Formation is the older one and is mainly built up of primitive picritic lavas and hyaloclastites, while the younger Maligât Formation is dominated by 
evolved feldspar-phyric basaltic lavas and minor hyaloclastites.

The Vaigat Formation on Disko has been divided into six members (Pedersen, 1985a), and in the northern part of Disko, where its base is below the present sea level, the thickness must exceed $1,600 \mathrm{~m}$. The Vaigat Formation was formed in two major events, separated in time by a period of low volcanic activity. The first igneous event gave rise to picritic rocks of the Naujánguit Member and to two minor volcanic systems enclosed therein. The two minor systems are composed of contaminated rocks and named the Asuk and Kûgánguaq Members. The olivinepoor and mostly feldspar-phyric tholeiitic basalts from the overlying Qordlortorssuaq Member (Pedersen, 1985a, b) constitute the waning phase of the first igneous event. The second igneous event gave rise to the picritic rocks of the Ordlingassoq Member which enclose the alkaline picrites and basalts of the Manitdlat Member. The picritic rocks and their quench glasses from the first igneous event on Disko are very low in incompatible elements (Pedersen, 1985b and unpublished data) and show considerable similarities to Tertiary picritic lavas and hyaloclastites from Baffin Island, described by Clarke (1970) and Clarke \& Upton (1971). Picrites from the second igneous event on Disko are relatively enriched in incompatible elements and many rocks show petrographic evidence of partial remelting and of mixing with alkaline melts (Pedersen, $1985 \mathrm{~b}$ and unpublished data). These picrites are chemically similar to picrites described from Svartenhuk Halv $\varnothing$ by Clarke (1970).

The Maligât Formation on Disko reaches a maximum thickness in excess of two kilometres. It has been divided into three members (Pedersen, 1975a) and is composed of tholeiitic basalts, most of which are feldspar-phyric and some olivine porphyritic. The lower member (Rinks Dal Member) is up to $1.5 \mathrm{~km}$ thick and is the only exposed volcanic unit over large areas in southern and eastern Disko. The two uppermost members (Nordfjord and Niaqussat Members) contain abundant contaminated volcanic rocks in addition to feldspar-phyric and olivine-porphyritic basalts. The uppermost basaltic lavas in the Niaqussat Member are olivine-porphyritic basalts of which at least one lava flow shows evidence of being affected by the remelting of gabbroic rocks.
Contaminated silica-enriched volcanic rocks

At least eight silica-enriched volcanic sequences occur in the Vaigat and Maligât Formations on Disko. Brief summaries on the silicic rocks are given by Pedersen (1975a, 1981). The silica-enriched volcanics were erupted from small volcanic systems and occur as lava series or tuff sequences intercalated with the regional plateau lavas. Volcanic necks and various intrusions (e.g. Ulff-Møller, 1977) form part of the volcanic systems. A prominent feature is the recurrence of composite lava flows and dykes, of which a basalt forms the first emplaced magma body to be followed by an andesitic magma pulse. Often these composite units carry native iron. In the basaltic pulse, effective segregation of native iron and sulphide into bodies up to several centimetres in size has often occurred and a cumulation of the dense phases is observed. In the andesite pulse iron and sulphides often show a dispersed distribution, and segregation of iron and sulphide into bodies more than a few millimetres in size is rare, and the cumulation of the dense phases have become ineffective. There is firm evidence that compositionally stratified magma bodies were established prior to the eruptions, which were probably triggered by a new input of hot basic magma. The order of appearance near or at the earth's surface was at least in part determined by the magma viscosities (Pedersen, 1975b). Furthermore there is a relation between the composition of the basic parental magma and the degree of silica-enrichment attained by the most evolved contaminated volcanic rocks. Thus contamination of the picrites and very LIL element depleted olivine-poor tholeiitic basalts in the Vaigat Formation led to the formation of not more evolved rocks than magnesian andesites (Table 2 and Pedersen, 1985a, b), while contamination of the evolved feldspar-phyric tholeiitic basalts of the Nordfjord Member in the Maligât Formation led to dacites and to very evolved two-feldspar rhyolites (Table 2 and Pedersen, 1975a, 1981).

\section{Age}

The Tertiary igneous activity in the Disko-Nûgssuaq area has not been dated in detail; existing evidence is briefly summarized by Hansen \& Pe- 
Table 1. Samples analysed for Sr-isotopes

\begin{tabular}{|c|c|c|c|c|}
\hline Samples & GGU no & Brief description & Locality & Reference \\
\hline 1 & 138230 & $\begin{array}{l}\text { Picrite (ol,pl,chr). Pillow in the } \\
\text { Naujánguit Member. }\end{array}$ & $\begin{array}{l}\text { Kugssinikavsak at altitude } \\
330^{\circ} \mathrm{m} \\
\left(70^{\circ} 14^{\prime} 25^{\prime \prime} \mathrm{N}, 53^{\circ} 41^{\prime} 50^{n} \mathrm{~W}\right)\end{array}$ & $\begin{array}{l}\text { Pedersen (1985a, } \\
\text { Section 10, fig. } 3 \\
\text { and Table 1) }\end{array}$ \\
\hline
\end{tabular}

2135977 Olivine microporphyritic basalt (ol,pl, chr). Pillow in the Naujánguit Member.

Kûgángûp ivnarta at altitude $35 \mathrm{~m}$

$\left(70^{\circ} 17^{\prime} 09^{\prime \prime} \mathrm{N}, 53^{\circ} 53^{\prime} 20^{\prime \prime} \mathrm{W}\right)$

$3176735 \quad$ Silicic basalt (opx). Base of composite lava with native iron in the Asuk Member.

176734 Magnesian andesite with native iron

- (opx,pl,ol). From the upper part of composite lava flow with native iron in the Asuk Member. Same lava as 3. Asuk Member.

113277 Silicic basalt with scarce native iron (opx). The lower part of composite lava flow with native iron in the Asuk Member.

$7 \quad 113280$

Magnesian andesite with native iron (opx,pl). The upper part of composite lava flow with native iron in the Asuk Member. Same lava flow as 6.

8

176727 Silicic basalt with very scarce native iron (opx). The lower part of composite lava flow with native iron in the Asuk Member.

9

176725 Magnesian andesite with native iron (opx,pl,ol). From the upper part of composite lava flow with native iron. Same lava flow as 8 .

264167 Olivine and clinopyroxene microporphyritic basalt (ol,cpx) with alkaline affinities. Volcanic neck in the Naujánguit Member.

138229
Olivine microporphyritic silicic basalt (ol,chr). Feeder dyke in the Kûgánguaq Member.

Olivine microporphyritic silicic basalt (ol,chr). Welded basaltic tuff in the Kûgánguaq Member.

Magnesian andesite (opx,ol,pl,chr). Lava flow in the Kûgánguaq Member.

Magnesian andesite (opx,ol,pl,chr). Lava flow in the Kûgánguaq Member.

Feldspar-phyric silicic basalt (pl,cpx, guaq Member.

Phenocryst poor dacite (pl,opx) rich in groundmass tridymite and with traces of native iron. Lava flow in the Nordfjord Member.

Dacite with native iron (pl,opx,il). Block in conglomerate in the Nordfjord Member. opx,ol,chr). Lava flow in the Kûgán-
Kûgánguaq valley at altitude $340 \mathrm{~m}$. $\left(70^{\circ} 06^{\prime} 37^{\prime \prime} \mathrm{N}, 53^{\circ} 41^{\prime} 54^{\prime \prime} \mathrm{W}\right)$

Kûgánguaq valley at altitude $375 \mathrm{~m}$. $\left(70^{\circ} 06^{\prime} 37^{\prime \prime} \mathrm{N}, 53^{\circ} 41^{\prime} 54^{n} \mathrm{~W}\right)$

Asuk at altitude $10 \mathrm{~m}$. $\left(70^{\circ} 11^{\prime} 56^{\prime \prime} \mathrm{N}, 53^{\circ} 18^{\prime} 01^{\prime \prime} \mathrm{W}\right)$

Asuk at altitude $20 \mathrm{~m}$ $\left(70^{\circ} 11^{\prime} 56^{\prime \prime} \mathrm{N}, 53^{\circ} 18^{\prime} 01^{\prime \prime} \mathrm{W}\right)$

Asuk at altitude $10 \mathrm{~m}$ ( $\left.70^{\circ} 11^{\prime} 56^{\prime \prime} \mathrm{N}, 53^{\circ} 18^{\prime} 01^{\prime \prime} \mathrm{W}\right)$ tude $395 \mathrm{~m}$ $\left(70^{\circ} 06^{\circ} 40^{\prime \prime} \mathrm{N}, 53^{\circ} 41^{\prime} 45^{\prime \prime} \mathrm{W}\right)$

Kûgánguaq valley at altitude $435 \mathrm{~m}$.

$\left(70^{\circ} 06^{\prime} 40^{\prime \prime} \mathrm{N}, 53^{\circ} 41^{\prime} 45^{\prime \prime} \mathrm{W}\right)$

Gully in Ametystskrænten, Stordal at altitude $350 \mathrm{~m}$.
$\left(70^{\circ} 01^{\prime} 12^{\prime \prime} \mathrm{N}, 54^{\circ} 01^{\prime} 58^{\prime \prime} \mathrm{W}\right)$

Kugssinikavsak at altitude $465 \mathrm{~m}$.

$\left(70^{\circ} 14^{\prime} 10^{\prime \prime} \mathrm{N}, 53^{\circ} 41^{\prime} 55^{\prime \prime} \mathrm{W}\right)$ tude $840 \mathrm{~m}$.

(70 13' $\left.57^{\prime \prime} \mathrm{N}, 53^{\circ} 52^{\prime} 00^{\prime \prime} \mathrm{W}\right)$

Harald Moltke Dal at altitude $840 \mathrm{~m}$. $\left(70^{\circ} 13^{\prime} 38^{\prime \prime} \mathrm{N}, 53^{\circ} 50^{\prime} 00^{\prime \prime} \mathrm{W}\right)$

Harald Moltke Dal at alti-

tude $870 \mathrm{~m}$.

Kûgánguaq valley at altitude $855 \mathrm{~m}$

Sarqardlît ilordlit, Mellemfjord at altitude $850 \mathrm{~m}$ $\left(69^{\circ} 45^{\prime} 00^{\prime \prime} \mathrm{N}, 54^{\circ} 32^{\prime} 39^{\prime \prime} \mathrm{W}\right)$

Gully $1 \mathrm{~km} \mathrm{E}$ of point $440 \mathrm{~N}$ of Hammers Dal at altitude $450 \mathrm{~m}$. $\left(70^{\circ} 10^{\prime} 00^{\prime \prime} \mathrm{N}, 54^{\circ} 40^{\prime} 00^{\prime \prime} \mathrm{W}\right)$
Kûgánguaq valley at alti-

Kûgánguaq valley at alti$\left(70^{\circ} 13^{\prime} 57^{\prime \prime} \mathrm{N}, 53^{\circ} 52^{\prime} 00^{\prime \prime} \mathrm{W}\right)$
Pedersen (1985a, Section 2, figs. 3 and 4)

Pedersen (1985a, Section 5 , figs. 3 and 9)

Pedersen (1985a, Section 5, figs. 3 and 9, Table 1)

Steenstrup (1900, Plate 11), Pedersen (1985a. Section 7 , figs. 3 and 9)

Pedersen (1985a Section 7, figs. 3 and 9, Table 1)

Pedersen (1985a, Section 7, figs. 3 and 9, Táble 1)

Pedersen (1985a Section 5, figs. 3 and 9)

Pedersen (1985a, Section 5, figs. 3 and 9)

Pedersen (1985a, p. 7)

Pedersen (1985b, Tables 18 and 25 )

Pedersen (1985b, Tables 18 and 25 )

Pedersen (1985a, Table 2) and Pedersen (1985b Tables 19 and 25 )

Pedersen (1985b Tables 19 and 25 )

Pedersen (1985a, Table 2) and Pedersen (1985b Tables 19 and 25 )

Pedersen (1977a, Table 7)

Pedersen (1981, Table 1) 
Table 1 continued

\begin{tabular}{|c|c|c|c|c|}
\hline Samples & GGU no & Brief description & Locality & Reference \\
\hline 18 & 176466 & $\begin{array}{l}\text { Dacite with native iron (pl,opx,il). } \\
\text { ?Lava flow in the Nordfjord Member. }\end{array}$ & $\begin{array}{l}\text { Jáma at altitude } 5 \mathrm{~m} \\
\left(70^{\circ} 12^{\prime} 00^{\prime \prime} \mathrm{N}, 54^{\circ} 50^{\prime} 36^{\prime \prime} \mathrm{W}\right)\end{array}$ & $\begin{array}{l}\text { Pedersen (1981, } \\
\text { Table 1) }\end{array}$ \\
\hline 19 & 176471 & $\begin{array}{l}\text { Dacite with traces of native iron (pl, } \\
\text { pig,opx,il).? Lava flow in the Nord- } \\
\text { fjord Member. }\end{array}$ & $\begin{array}{l}\text { On the coast between Igd- } \\
\text { lorpait and Jáma at alti- } \\
\text { tude } 3 \mathrm{~m} \text {. } \\
\left(70^{\circ} 12^{\prime} 54^{\prime \prime} \mathrm{N}, 54^{\circ} 49^{\prime} 48^{\prime \prime} \mathrm{W}\right)\end{array}$ & $\begin{array}{l}\text { Pedersen }(1981, \\
\text { Table 1) }\end{array}$ \\
\hline 20 & 156518 & $\begin{array}{l}\text { Rhyolitic glass rock with garnet and } \\
\text { graphite (pl,qz,opx,bi,gt,il,ap,zr). Block } \\
\text { in conglomerate in the Nordfjord } \\
\text { Member. }\end{array}$ & $\begin{array}{l}\text { Sedimentkløften in Ham- } \\
\text { mers Dal at altitude } 140 \mathrm{~m} \text {. } \\
\left(70^{\circ} 07^{\prime} 40^{\prime \prime} \mathrm{N}, 54^{\circ} 46^{\prime} 50^{\prime \prime} \mathrm{W}\right)\end{array}$ & $\begin{array}{l}\text { Pedersen (1975, } \\
\text { 1977b) }\end{array}$ \\
\hline 21 & 156516 & $\begin{array}{l}\text { Rhyolitic glass rock with graphite and } \\
\text { traces of garnet (qz,pl,sa,bi,gt,). Block } \\
\text { in conglomerate in the Nordf jord } \\
\text { Member. }\end{array}$ & $\begin{array}{l}\text { Sedimentkløften in Ham- } \\
\text { mers Dal at altitude } 140 \mathrm{~m} \text {. } \\
\left(70^{\circ} 07^{\prime} 40^{\prime \prime} \mathrm{N}, 54^{\circ} 46^{\prime} 50^{\prime \prime} \mathrm{W}\right)\end{array}$ & $\begin{array}{l}\text { Pedersen }(1975 \\
\text { 1977b) }\end{array}$ \\
\hline 22 & 176565 & $\begin{array}{l}\text { Olivine and plagioclase porphyritic ba- } \\
\text { salt (ol,pl). The base of composite lava } \\
\text { flow with native iron in the Niaqussat } \\
\text { Member. }\end{array}$ & $\begin{array}{l}3.5 \mathrm{~km} \text { W of Sargardlit } \\
\text { silardlît, Mellemfjord at } \\
450 \mathrm{~m} \text {. } \\
\left(69^{\circ} 47^{\prime} 34^{\prime \prime} \mathrm{N}, 54^{\circ} 48^{\prime} 13^{\prime \prime} \mathrm{W}\right)\end{array}$ & $\begin{array}{l}\text { Pedersen (1977a, } \\
\text { Table 8) }\end{array}$ \\
\hline 23 & 176564 & $\begin{array}{l}\text { Magnesian andesite with native iron } \\
\text { (opx, pig,pl). The base of the andesitic } \\
\text { part of composite lava flow in the Nia- } \\
\text { qussat Member. Same lava flow as } 22 \text {. }\end{array}$ & $\begin{array}{l}3.5 \mathrm{~km} \text { W of Sargardlit } \\
\text { silardlitt, Mellemfjord at } \\
452 \mathrm{~m} \text {. } \\
\left(69^{\circ} 47^{\prime} 34^{\prime \prime} \mathrm{N}, 54^{\circ} 48^{\prime} 13^{\prime \prime} \mathrm{W}\right)\end{array}$ & $\begin{array}{l}\text { Pedersen }(1977 a, \\
\text { Table 8) }\end{array}$ \\
\hline 24 & 176448 & $\begin{array}{l}\text { Magnesian andesite with native iron } \\
\text { (opx,pig,pl). Lava flow in the Nia- } \\
\text { qussat Member. }\end{array}$ & $\begin{array}{l}\text { Hammers Dal at altitude } \\
500 \mathrm{~m} \cdot \\
\left(70^{\circ} 09^{\prime} 18^{\prime \prime} \mathrm{N}, 54^{\circ} 40^{\prime} 12^{\prime \prime} \mathrm{W}\right)\end{array}$ & $\begin{array}{l}\text { Pedersen (1977b, } \\
\text { Fig. 7, unit D) } \\
\text { and Pedersen } \\
\text { (1981, Table 1) }\end{array}$ \\
\hline 25 & 176411 & $\begin{array}{l}\text { Andesite with native iron (pl,opx,pig,il, } \\
\text { arm). The base of lava flow close to } \\
\text { its feeder crater in the Niaqussat } \\
\text { Member. }\end{array}$ & $\begin{array}{l}\text { Close to point } 500 \text { at Nia- } \\
\text { qussat at altitude } 400 \mathrm{~m} \text { - } \\
\left(70^{\circ} 10^{\prime} 18^{\prime \prime} \mathrm{N}, 54^{\circ} 39^{\prime} 36^{\prime \prime} \mathrm{W}\right)\end{array}$ & $\begin{array}{l}\text { Pedersen }(1981, \\
\text { Table 1) }\end{array}$ \\
\hline 26 & 176669 & $\begin{array}{l}\text { Silicic basalt with traces of native iron } \\
\text { (ol). Glass rock from basaltic dyke } \\
\text { with native iron assigned to the Nia- } \\
\text { qussat Member. }\end{array}$ & $\begin{array}{l}\text { Luciefjeld at altitude } \\
515 \mathrm{~m} \cdot \\
\left(69^{\circ} 19^{\prime} 17^{\prime \prime} \mathrm{N}, 53^{\circ} 46^{\prime} 41^{\prime \prime} \mathrm{W}\right)\end{array}$ & $\begin{array}{l}\text { Pedersen (1979a, } \\
\text { Table 2) }\end{array}$ \\
\hline 27 & 113202 & $\begin{array}{l}\text { Sandstone probably belonging to the } \\
\text { Atane Formation. }\end{array}$ & $\begin{array}{l}\text { Manitdlat kugssinerssuat at } \\
\text { altitude } 360 \mathrm{~m} \text {. } \\
\left(70^{\circ} 13^{\prime} 33^{\prime \prime} \mathrm{N}, 53^{\circ} 33^{\prime} 06^{\prime \prime} \mathrm{W}\right)\end{array}$ & $\begin{array}{l}\text { Pedersen (1985a, } \\
\text { Fig. } 4 \text { section 4) }\end{array}$ \\
\hline 28 & 176506 & $\begin{array}{l}\text { Sandstone buchite with traces of native } \\
\text { iron. Xenolith in andesite lava with na- } \\
\text { tive iron in the Niaqussat Member. }\end{array}$ & $\begin{array}{l}\text { Plateau east of Tôrnivit at } \\
\text { altitude } 450 \mathrm{~m} \text {. } \\
\left(70^{\circ} 14^{\prime} 40^{\prime \prime} \mathrm{N}, 54^{\circ} 43^{\prime} 10^{\prime \prime} \mathrm{W}\right)\end{array}$ & $\begin{array}{l}\text { The area is brief- } \\
\text { ly described in } \\
\text { Pedersen }(1977 \mathrm{~b})\end{array}$ \\
\hline 29 & 176770 & $\begin{array}{l}\text { Composite sample of } 11 \text { unmetamor- } \\
\text { phosed Mesozoic to early Tertiary } \\
\text { shales. }\end{array}$ & Nuggssuaq. & $\begin{array}{l}\text { Pedersen (1979b, } \\
\text { Table 1) and } \\
\text { Pedersen (1985b, } \\
\text { Table 25) }\end{array}$ \\
\hline 30 & 136992 & $\begin{array}{l}\text { Shale buchite with native iron and alu- } \\
\text { minous armalcolite. Xenolith in the } \\
\text { lower part of composite lava flow with } \\
\text { native iron in the Asuk Member. }\end{array}$ & $\begin{array}{l}\text { Asuk at altitude } 20 \mathrm{~m} \text {. } \\
\left(70^{\circ} 11^{\prime} 56^{\prime \prime} \mathrm{N}, 53^{\circ} 18^{\prime} 01^{\prime \prime} \mathrm{W}\right)\end{array}$ & $\begin{array}{l}\text { Pedersen }(1979 b, \\
\text { Table 1) }\end{array}$ \\
\hline 31 & 113306 & $\begin{array}{l}\text { Modified shale xenolith (plagioclase-spi- } \\
\text { nel-graphite rock). Xenolith in the an- } \\
\text { desitic part of composite lava flow with } \\
\text { native iron in the Asuk Member. }\end{array}$ & $\begin{array}{l}\text { Asuk at altitude } 25 \mathrm{~m} \text {. } \\
\left(70^{\circ} 11^{\prime} 56^{\prime \prime} \mathrm{N}, 53^{\circ} 18^{\prime} 01^{\prime \prime} \mathrm{W}\right)\end{array}$ & $\begin{array}{l}\text { Pedersen }(1979 b \text {, } \\
\text { Table 1) }\end{array}$ \\
\hline
\end{tabular}

Phenocrystic phases: ol: olivine, opx: orthopyroxene, cpx: calcic clinopyroxene, pig: pigeonite, pl: plagioclase, chr: chromite, il: ilmenite, arm: armalcolite, ap: apatite, qz: quartz, sa: sanidine, bi: biotite, gt: garnet.

dersen (1985). Sediments contemporaneous with or slightly older than the early volcanic rocks are assigned a middle Paleocene age (Henderson et al., 1981); and palaeomagnetic work by Athavale \& Sharma (1975) indicates that the Vaigat Formation and at least the lower $500 \mathrm{~m}$ of the Mali- gât Formation were erupted in the time span represented by geomagnetic anomaly 25 and the long reversal period between anomalies 25 and 24. The present age estimate for this period is 56 to $52 \mathrm{Ma}$ (Butler \& Coney, 1981). Hansen \& Pedersen (1985) report on fission track dating of 
zircon in thyolitic glass blocks from the Nordfjord Member in NW Disko. An age of ca. $45 \mathrm{Ma}$ is obtained. The ${ }^{87} \mathrm{Sr} /{ }^{86} \mathrm{Sr}$ ratios discussed in the following are recalculated assuming an age of 55 Ma. In addition the rhyolites were also recalculated for an age of $45 \mathrm{Ma}$.

\section{Sr isotope analyses}

Sample selection

In order to characterize the silicic rocks ten samples of such rocks were selected from the Vaigat Formation, while seven samples, of which one represents a dyke, were selected from the Maligât Formation. Furthermore, four samples of Mesozoic to Tertiary sediments or sedimentary xenoliths from the volcanic rocks were selected for the study. These additional samples constitute, together with ten already published $\mathrm{Sr}$ isotope analyses from Disko, the present data set. The samples include one picrite, eleven basalts, nine andesites, three dacites, two rhyolites and five heated or unheated sediments. The sample locations and stratigraphic positions and a brief petrographic characterization are given in Table 1, while Table 2 presents major and trace element compositions for selected samples.

\section{Analytical work}

The $\mathrm{Rb} / \mathrm{Sr}$ ratios were obtained by $\mathrm{X}$-ray fluorescence analysis, using an automatic Philips pw 1400 instrument. $\mathrm{Rb}$ and $\mathrm{Sr}$ concentrations were calculated from the X-ray fluorescence measurements. Matrix corrections were performed using the major element analyses and the mass absorption coefficients of Heinrich (1966). The Sr isotope ratios were measured using a Varian MAT TH-5 mass spectrometer and normalized to a ${ }^{87} \mathrm{Sr}{ }^{86} \mathrm{Sr}$ value of $0.70800\left({ }^{88} \mathrm{Sr}{ }^{86} \mathrm{Sr}\right.$ : 8.3752$)$ for the Eimer and $\mathrm{Amend} \mathrm{SrCO}_{3}$ standard. An overall laboratory reproducibility (including the chemistry) of 0.16 per mill $(=0.00012)$ on the $95 \%$ confidence level for biotite free samples with low ${ }^{87} \mathrm{Sr} /{ }^{16} \mathrm{Sr}$ ratios was determined from a suite of 21 double determinations during the period of investigation.

$\mathrm{A}^{87} \mathrm{Rb}$ decay constant of $1.42 \times 10^{-11} \mathrm{a}^{-1}$ is used in the recalculations.

Picritic to basaltic volcanic rocks of regional extension

$\mathrm{Sr}$ isotope analyses are presented in Table 3 and are shown on Figs 2, 4 and 5 together with previously published isotope analyses of Tertiary basaltic rocks from Baffin Island and Svartenhuk Halvø (Carter et al., 1979). The values from these two areas show mutual overlap within the range ${ }^{87} \mathrm{Sr} /{ }^{86} \mathrm{Sr}=0.703$ to 0.704 , which is taken as an approximative value for the mantle in the Baffin Bay area 55 Ma ago. Carter et al. (1979) concluded that the typical tholeiitic basalts were derived from a mantle which had much earlier been depleted in $\mathrm{Rb}$ relative to $\mathrm{Sr}$. The Disko picrite (Table 3 no. 1) has a $\mathrm{Sr}$ isotope ratio (0.7033) representative of tholeiitic picrites and basalts of the Baffin Bay area.

\section{Silica-enriched volcanic rocks}

As shown in Table 3 and fig. 2 the analysed basalts have ${ }^{87} \mathrm{Sr}^{86} \mathrm{Sr}_{\mathrm{o}}$ ratios from 0.7043 to 0.7118 , the andesites from 0.7097 to 0.7155 , the dacites from 0.7132 to 0.7147 and the two analysed rhyolites from 0.7176 to 0.7203 (if the rhyolites are corrected to $45 \mathrm{Ma}$, then ${ }^{87} \mathrm{Sr}^{86} \mathrm{Sr}_{o}$ varies only from 0.7204 to 0.7206 ). Two basaltic rocks from respectively a volcanic neck in the Naujánguit Member (Table 3 no. 10) and a lower chill zone in a composite lava with native iron from the Niaqussat Member (Table 3 no. 22) have Sr isotope ratios between 0.7043 and 0.7049 and are apparently almost uncontaminated. The other nine basalt samples vary from ${ }^{87} \mathrm{Sr}^{186} \mathrm{Sr}_{\mathrm{o}}=0.7076$ to 0.7118 and are all distinctly contaminated with ${ }^{87} \mathrm{Sr}$. All rocks more silicic than basalts show evidence of extensive contamination with ${ }^{87} \mathrm{Sr}$ (fig. 3 ), and it is concluded that no silica-enriched volcanic rock on Disko has evolved through closed system fractionation of a mantle derived 


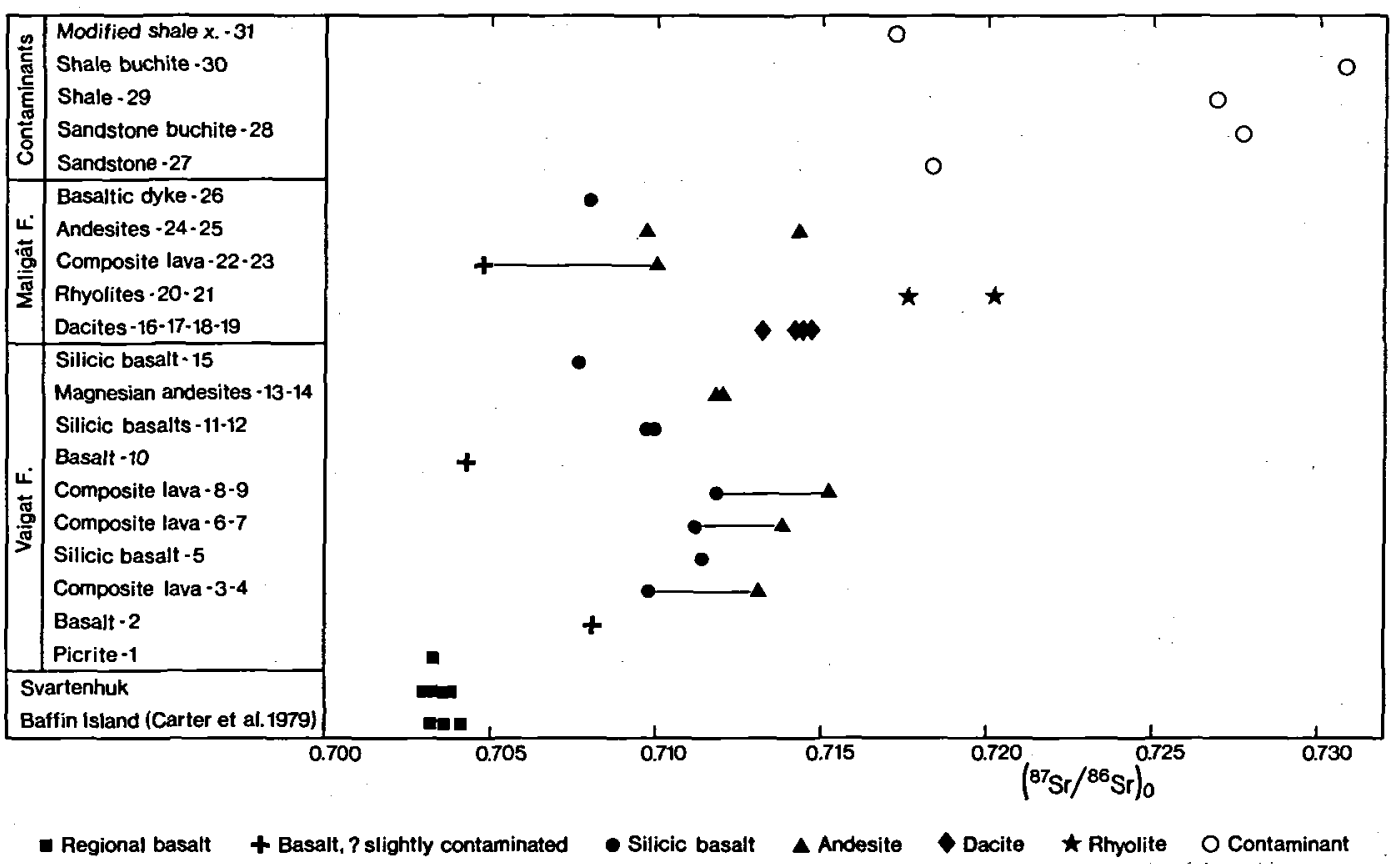

Fig. 2. The range of ${ }^{87} \mathrm{Sr}{ }^{86} \mathrm{Sr}$ ratios $55 \mathrm{Ma}$ ago of analysed Tertiary volcanic rocks from Disko together with potential contaminants. Lines connect sample pairs taken from composite lava flows. Below is shown the Sr-isotope composition of some picritic to feldspar-phyric tholeiitic regional basalts from Baffin Island and Svartenhuk Halvø (Carter et al., 1979).

basaltic magma. This contrasts with the Tertiary evolved alkaline trachyte from Svartenhuk Halvø, which is $\mathrm{Sr}$ isotopically indistinguishable from the tholeiitic basalts of regional extension (O’Nions \& Clarke, 1972).

\section{Interpretation: Quantification of the contamination process}

In order to investigate mechanisms which could have caused the observed marked contamination of the silica-enriched volcanic rocks we have considered simple mixing and combined $A$ ssimilation and Fractional Crystallization (AFC) with respect to $\mathrm{Sr}$ applying the equations given by $\mathrm{De}$ Paolo (1981, 1985). In the following AFC and simple mixing processes are tested on ${ }^{87} \mathrm{Sr}^{86} \mathrm{Sr}_{0}$ versus $\mathrm{Sr}$ diagrams. ${ }^{87} \mathrm{Sr} /{ }^{86} \mathrm{Sr}_{\mathrm{o}}$ versus $1 / \mathrm{Sr}$ mixing diagrams for samples from the Vaigat and Maligât Formations are given in fig. 5a and b. As evident from these diagrams no solutions involving simple mixing with only one contaminant and a single parental precursor can be used in interpretation of the data. In the AFC calculations, unless stated otherwise, the $\mathrm{Sr}$ isotope ratios used have been recalculated to ${ }^{87} \mathrm{Sr} /{ }^{86} \mathrm{Sr} 55 \mathrm{Ma}$ ago and an initial Sr isotope ratio of 0.7035 of the parental material has been assumed. The $\mathrm{Sr}$ concentration of the parental material used in the AFC-considerations has been estimated from other geochemical evidence (see Table 5). This estimated composition was used as a first approximation in the AFC calculations and the AFC curves were drawn on the basis of repeated calculations in order to obtain a best fit through the contaminant, the sample and the initial $\mathrm{Sr}$ isotope ratio. In one case a slightly evolved basalt has been used as parental material.

An essential parameter in the model calculations given below is $D^{S_{r}}$, the weight bulk partition coefficient for Sr between the solid phases and the silicate melt. In order to interpret the $D$ values in terms of potential fractionating phases, we have used mineral/melt partition coefficients given in table 4 for the phases olivine, augite, orthopyroxene, plagioclase and sanidine. Since the evolution from parent to contaminated volcanic rocks in many cases must span quite a range in temperature, and hence represent a range in individual mineral/melt $\mathrm{D}^{\mathrm{Sr}}$ values, only crude partition coefficient values are given. 
Table 2. Chemical analyses of volcanic rocks from Disko and some potential contaminants

\begin{tabular}{|c|c|c|c|c|c|c|c|c|c|}
\hline $\begin{array}{l}\text { Analysis } \\
\text { GGU no }\end{array}$ & $\underset{138230}{1}$ & $\begin{array}{c}6 \\
113277\end{array}$ & $\begin{array}{c}7 \\
113280\end{array}$ & $\begin{array}{c}10 \\
264167\end{array}$ & $\begin{array}{c}12 \\
113380\end{array}$ & $\begin{array}{c}13 \\
135924\end{array}$ & $\begin{array}{c}16 \\
176555\end{array}$ & $\begin{array}{c}20 \\
156518\end{array}$ & $\begin{array}{c}21 \\
156516\end{array}$ \\
\hline $\begin{array}{l}\mathrm{SiO}_{2} \\
\mathrm{TiO}_{2} \\
\mathrm{Al}_{2} \mathrm{O}_{3} \\
\mathrm{Fe}_{2} \mathrm{O}_{3} \\
\mathrm{FeO} \\
\mathrm{Fe}^{\circ} \\
\mathrm{MnO} \\
\mathrm{MgO} \\
\mathrm{CaO} \\
\mathrm{Na}_{2} \mathrm{O} \\
\mathrm{K}_{2} \mathrm{O} \\
\mathrm{P}_{2} \mathrm{O}_{3} \\
\mathrm{H}_{2} \mathrm{O}^{+} \\
\mathrm{H}_{2} \mathrm{O}^{-} \\
\mathrm{C} \\
\mathrm{CO}_{2} \\
\mathrm{~S} \\
\text { Less O } \\
\text { excess } 1 . \text { o.i }\end{array}$ & $\begin{array}{r}43.96 \\
0.86 \\
9.10 \\
2.29 \\
8.94 \\
\\
0.18 \\
22.27 \\
7.81 \\
1.08 \\
0.04 \\
0.06 \\
1.40 \\
0.50 \\
\\
0.50\end{array}$ & $\begin{array}{r}52.68 \\
1.28 \\
15.40 \\
1.14 \\
8.02 \\
\\
0.16 \\
7.49 \\
9.23 \\
2.09 \\
0.57 \\
0.13 \\
1.05 \\
\\
0.03 \\
0.07 \\
0.10 \\
0.05\end{array}$ & $\begin{array}{c}55.77 \\
1.09 \\
15.67 \\
\\
4.94 \\
2.9 \\
0.14 \\
6.04 \\
7.78 \\
2.55 \\
0.94 \\
0.14 \\
0.98 \\
\\
0.30 \\
0.03 \\
0.48 \\
0.24\end{array}$ & $\begin{array}{r}46.95 \\
1.80 \\
13.96 \\
4.75 \\
6.06 \\
\\
0.16 \\
7.61 \\
12.77 \\
1.80 \\
0.71 \\
0.41 \\
2.33\end{array}$ & $\begin{array}{r}0.19 \\
11.65 \\
8.44 \\
1.67 \\
0.68 \\
0.13 \\
1.06\end{array}$ & $\begin{array}{r}56.24 \\
1.00 \\
13.30 \\
3.50 \\
4.68 \\
\\
0.25 \\
8.95 \\
6.95 \\
2.30 \\
0.72 \\
0.17 \\
1.33\end{array}$ & $\begin{array}{r}62.86 \\
2.27 \\
12.82 \\
1.05 \\
8.88 \\
\\
0.16 \\
2.03 \\
6.34 \\
2.45 \\
0.85 \\
0.54 \\
1.69^{\circ}\end{array}$ & $\begin{array}{l}0.05 \\
0.54 \\
2.12 \\
2.50 \\
3.82 \\
0.20 \\
2.52 \\
\\
0.13\end{array}$ & $\begin{array}{l}0.03 \\
0.16 \\
0.58 \\
2.29 \\
5.73 \\
0.07 \\
3.99 \\
0.20\end{array}$ \\
\hline $\begin{array}{l}\text { Total } \\
\mathrm{FeO}^{*}\end{array}$ & $\begin{array}{l}98.99 \\
11.00\end{array}$ & $\begin{array}{r}99.39 \\
9.05\end{array}$ & $\begin{array}{r}99.51 \\
8.47\end{array}$ & $\begin{array}{l}99.31 \\
10.34\end{array}$ & $\begin{array}{r}100.35 \\
9.34\end{array}$ & $\begin{array}{r}99.39 \\
7.83\end{array}$ & $\begin{array}{r}100.25 \\
9.83\end{array}$ & $\begin{array}{r}99.41 \\
3.82\end{array}$ & $\begin{array}{r}99.42 \\
1.33\end{array}$ \\
\hline $\begin{array}{l}\text { Trace elem } \\
\mathrm{Sc} \\
\mathrm{V} \\
\mathrm{Cr} \\
\mathrm{Ni} \\
\mathrm{Cu} \\
\mathrm{Rb} \\
\mathrm{Sr} \\
\mathrm{Y} \\
\mathrm{Zr} \\
\mathrm{Nb} \\
\mathrm{Ba} \\
\mathrm{La} \\
\mathrm{Ce} \\
\mathrm{Nd}\end{array}$ & $\begin{array}{c}\text { in ppm } \\
34 \\
234 \\
1990 \\
1300 \\
118 \\
0.9 \\
86 \\
15 \\
45 \\
3 \\
22 \\
<3 \\
<2 \\
3\end{array}$ & $\begin{array}{r}36 \\
266 \\
355 \\
56 \\
41 \\
20 \\
198 \\
25 \\
106 \\
3 \\
165 \\
14 \\
25 \\
14\end{array}$ & $\begin{array}{r}32 \\
219 \\
333 \\
140 \\
119 \\
32 \\
228 \\
24 \\
146 \\
5 \\
300 \\
20 \\
42 \\
21\end{array}$ & $\begin{array}{r}33 \\
282 \\
326 \\
65 \\
64 \\
17 \\
580 \\
27 \\
127 \\
65 \\
555 \\
72 \\
128 \\
59\end{array}$ & $\begin{array}{r}37 \\
260 \\
1300 \\
40 \\
18 \\
23 \\
159 \\
23 \\
109 \\
5 \\
160 \\
13 \\
24 \\
16\end{array}$ & $\begin{array}{r}27 \\
191 \\
852 \\
208 \\
55 \\
68 \\
210 \\
21 \\
133 \\
8 \\
371 \\
28 \\
42 \\
24\end{array}$ & $\begin{array}{r}33 \\
103 \\
62 \\
60 \\
18 \\
29 \\
321 \\
35 \\
449 \\
15 \\
549 \\
24 \\
54 \\
35\end{array}$ & $\begin{array}{r}35 \\
16 \\
7 \\
6 \\
12 \\
124 \\
173 \\
39 \\
313 \\
\text { n.a. } \\
820 \\
49 \\
93 \\
45\end{array}$ & $\begin{array}{r}25 \\
6 \\
3 \\
4 \\
4 \\
194 \\
29 \\
53 \\
72 \\
\text { n.a. } \\
187 \\
16 \\
34 \\
14\end{array}$ \\
\hline
\end{tabular}

$\mathrm{Fe}^{\circ}$ : Metallic iron; $\mathrm{FeO}^{*}$ : Total iron as $\mathrm{FeO} ; \nabla$ : Total loss of ignition; n.a.: Not analysed for.

Major element chemistry: XRF analyses, GGU's chemical laboratories; S and trace elements: XRF analyses at Institute of Petrology, University of Copenhagen.

\section{Contaminants}

Shales and sandstones, and their magma modified equivalents completely dominate the xenolith assemblages in the silica-enriched volcanic rocks. For this reason it is assumed in the calculations that only one of two possible contaminants were involved. These contaminants are a) a "mean" shale (mean of the investigated shales, no. 29 (GGU 176770) and 30 (GGU 136992)) with a $\mathrm{Sr}$ concentration of $170 \mathrm{ppm}$ and a ${ }^{87} \mathrm{Sr}^{86} \mathrm{Sr}_{\mathrm{o}}$ ratio of 0.729 and $\mathrm{b}$ ) sandstones as exemplified by sample 27 (GGU 113202) with a $\mathrm{Sr}$ concentration of $362 \mathrm{ppm}$ and ${ }^{87} \mathrm{Sr}^{86} \mathrm{Sr}_{\mathrm{o}}$ ratio of 0.7183 . The contaminants are considered to be of Cretaceous to early Tertiary age such as the exposed sediments in the Disko-Nûgssuaq area (Henderson et al., 1976). Accordingly the contaminating $\mathrm{Sr}$ has only a negligible independent radiogenic ${ }^{87} \mathrm{Sr}$-component. The composition of the shale contaminant is fairly well-constrained with respect to $\mathrm{Sr}$-concentration as demonstrated on a $\mathrm{Sr}$ versus $\mathrm{CaO}$-diagram (fig. 6), and the diagram demonstrates that the shale-magma reaction leads to a very marked increase in $\mathrm{Ca}$ of 
Table 2 continued

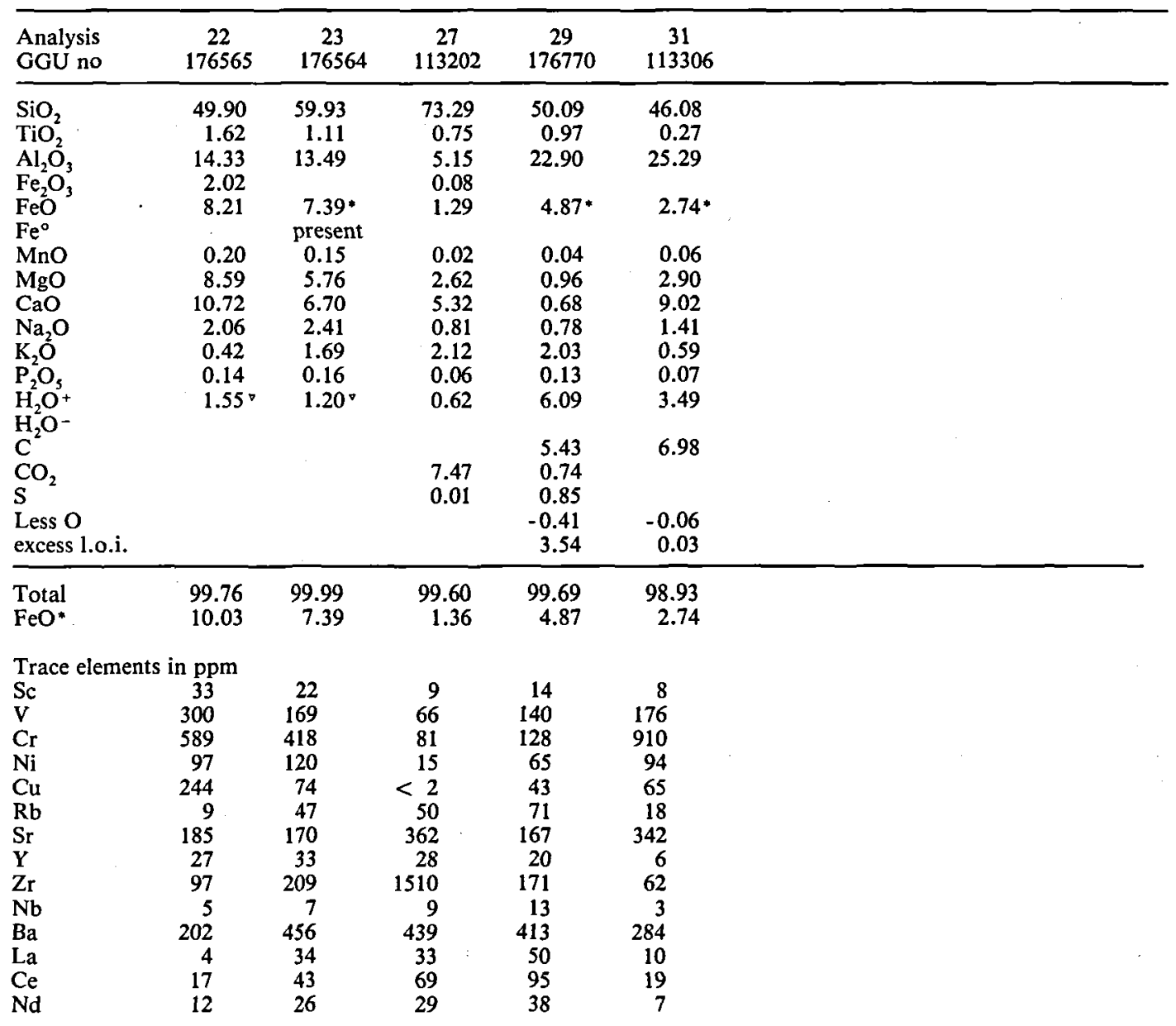

the shale and to a relative increase in Sr of about 40 to $100 \%$.

The sandstone contaminant is on the other hand poorly constrained. The analysed sand- and siltstones and xenoliths of these materials show a very substantial scatter in $\mathrm{Sr}$ concentrations (fig. 6) and $\mathrm{Sr}$ is only partly correlated with $\mathrm{Ca}$ (and carbonates) in the rocks. Any modelling on the effects of sandstone contamination based on a few samples will have its obvious limitations.

A third potential contaminant is Precambrian gneisses from the crust underlying Disko. Scarce gneiss xenoliths are known from a few volcanic units resting on or cutting the Disko Gneiss Ridge. We have abstained from involving Precambrian gneiss in our crude modelling because of the scarcity of xenoliths and the difficulty in defining a well constrained contaminant.

Table 5 summarizes the results of AFC calculations on ${ }^{87} \mathrm{Sr} /{ }^{86} \mathrm{Sr}_{\mathrm{o}}$ and $\mathrm{Sr}$ in silica-enriched volcanic rocks from Disko applying the two model contaminants presented above.

\section{Silica-enriched rocks from the Vaigat Formation}

\section{Kûgánguaq Member}

The best studied Tertiary volcanic rocks in the area are the silicic basalts and magnesian andesites from the Kûgánguaq Member (Pedersen, 


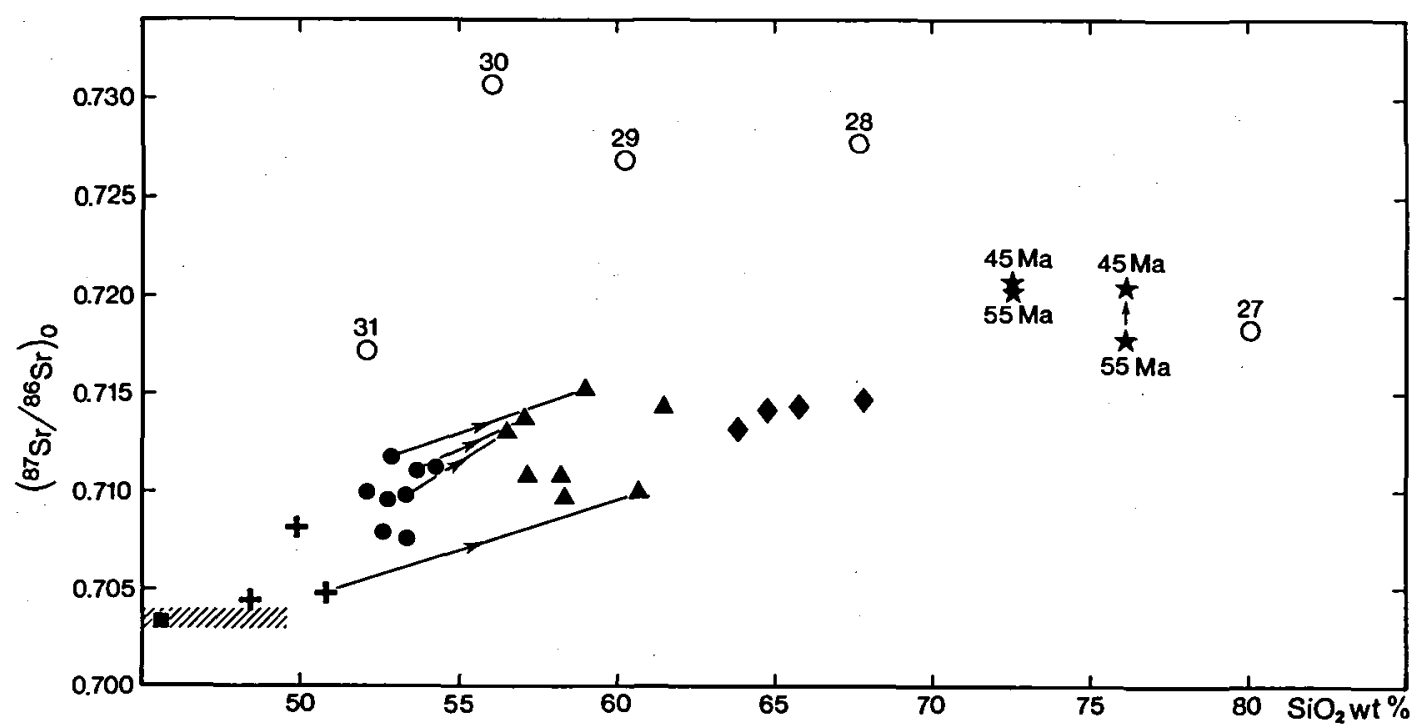

Fig. $3 .{ }^{87} \mathrm{Sr} /{ }^{86} \mathrm{Sr}$ ratios $55 \mathrm{Ma}$ ago versus $\mathrm{SiO}_{2}$ of Tertiary volcanic rocks from Disko and their potential contaminants. Shaded signature shows Baffin Island and Svartenhuk Halvø picrites and basalts. The rhyolites have also been calculated at $45 \mathrm{Ma}$. Symbols as in fig. 2. The numbers refer to samples presented in Tables 1 to 3 .

Table 3. Rb and Sr data of samples from Disko

\begin{tabular}{|c|c|c|c|c|c|c|}
\hline No & GGU no & $\mathbf{R b}($ ppm $)$ & Sr(ppm) & $\mathrm{Rb} / \mathrm{Sr}$ & ${ }^{87} \mathrm{Sr} /{ }^{86} \mathrm{Sr}_{\mathrm{m}}$ & ${ }^{87} \mathrm{Sr} /{ }^{86} \mathrm{Sr}_{\mathrm{o}}$ \\
\hline 1 & 138230 & 0.9 & 86 & 0.007 & 0.70330 & 0.7033 \\
\hline 2 & 135977 & 5 & 151 & 0.039 & 0.70820 & 0.7081 \\
\hline 3 & 176735 & 18 & 166 & 0.108 & 0.71008 & 0.7098 \\
\hline 4 & 176734 & 29 & 191 & 0.144 & 0.71341 & 0.7131 \\
\hline 5 & 113271 & 17 & 192 & 0.072 & 0.71160 & 0.7114 \\
\hline 6 & 113277 & 20 & 198 & 0.104 & 0.71132 & 0.7111 \\
\hline 7 & 113280 & 32 & 228 & 0.141 & 0.71414 & 0.7138 \\
\hline 8 & 176727 & 4 & 202 & 0.021 & 0.71187 & 0.7118 \\
\hline 9 & 176725 & 46 & 243 & 0.182 & 0.71560 & 0.7152 \\
\hline 10 & 264167 & 17 & 580 & 0.029 & 0.70433 & 0.7043 \\
\hline 11 & 138229 & 13 & 169 & 0.084 & 0.70990 & 0.7097 \\
\hline 12 & 113380 & 23 & 159 & 0.157 & 0.71021 & 0.7099 \\
\hline 13 & 135924 & 68 & 210 & 0.334 & 0.71152 & 0.7108 \\
\hline 14 & 135927 & 60 & 199 & 0.323 & 0.71162 & 0.7109 \\
\hline 15 & 135972 & 4 & 273 & 0.017 & 0.70766 & 0.7076 \\
\hline 16 & 176555 & 29 & 321 & 0.089 & 0.71345 & 0.7132 \\
\hline 17 & 176486 & 54 & 245 & 0.220 & 0.71491 & 0.7144 \\
\hline 18 & 176466 & 54 & 243 & 0.222 & 0.71471 & 0.7142 \\
\hline 19 & 176471 & 64 & 192 & 0.333 & 0.71541 & 0.7147 \\
\hline 20 & 156518 & 124 & 173 & 0.721 & 0.72190 & 0.7203 \\
\hline 21 & 156516 & 194 & 29 & 6.83 & 0.73307 & 0.7176 \\
\hline 22 & 176565 & 9 & 185 & 0.047 & 0.70502 & 0.7049 \\
\hline 23 & 176564 & 47 & 170 & 0.277 & 0.71067 & 0.7100 \\
\hline 24 & 176448 & 35 & 201 & 0.181 & 0.71009 & 0.7097 \\
\hline 25 & 176411 & 49 & 232 & 0.211 & 0.71478 & 0.7143 \\
\hline 26 & 176669 & 16 & 188 & 0.085 & 0.70822 & 0.7080 \\
\hline 27 & 113202 & 50 & 362 & 0.135 & 0.71861 & 0.7183 \\
\hline 28 & 176506 & 43 & 250 & 0.170 & 0.72808 & 0.7277 \\
\hline 29 & 176770 & 71 & 167 & 0.448 & 0.72786 & 0.7269 \\
\hline 30 & 136992 & 102 & 171 & 0.613 & 0.73218 & 0.7308 \\
\hline 31 & 113306 & 18 & 342 & 0.054 & 0.71730 & 0.7172 \\
\hline
\end{tabular}

${ }^{87} \mathrm{Sr}^{866} \mathrm{Sr}_{\mathrm{m}}$ : measured $\mathrm{Sr}$ isotope ratio ${ }^{87} \mathrm{Sr} /{ }^{86} \mathrm{Sr}_{\mathrm{o}}$ : $\mathrm{Sr}$ isotope ratio $55 \mathrm{Ma}$ ago 

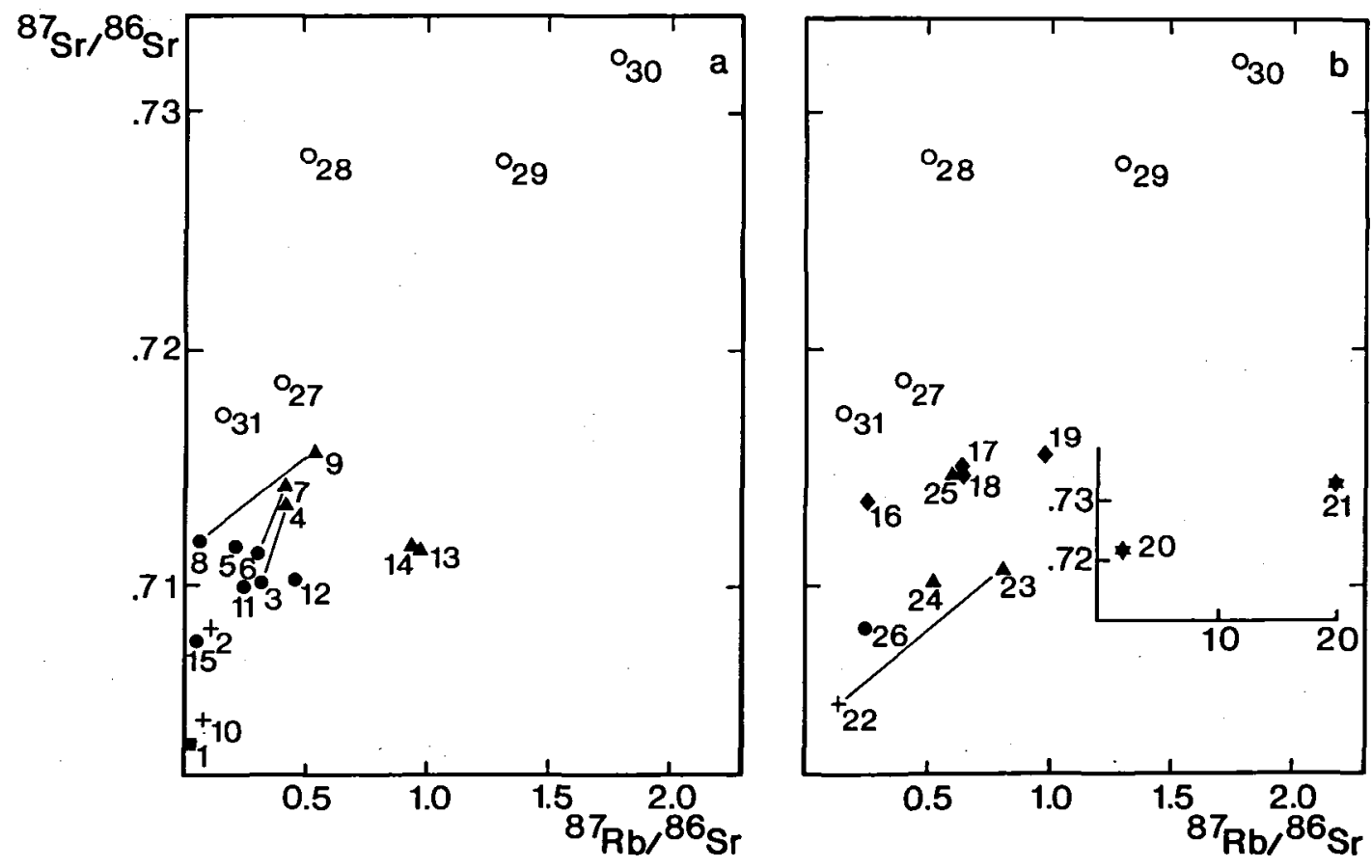

Fig. 4. Rb-Sr isochron diagrams for samples from (a) the Vaigat Formation and (b) the Maligât Formation. Numbers labelling symbols in this and the following diagrams refer to numbers in Tables 1 to 3. Lines connect samples taken from composite lava flows. Symbols as in fig. 2.
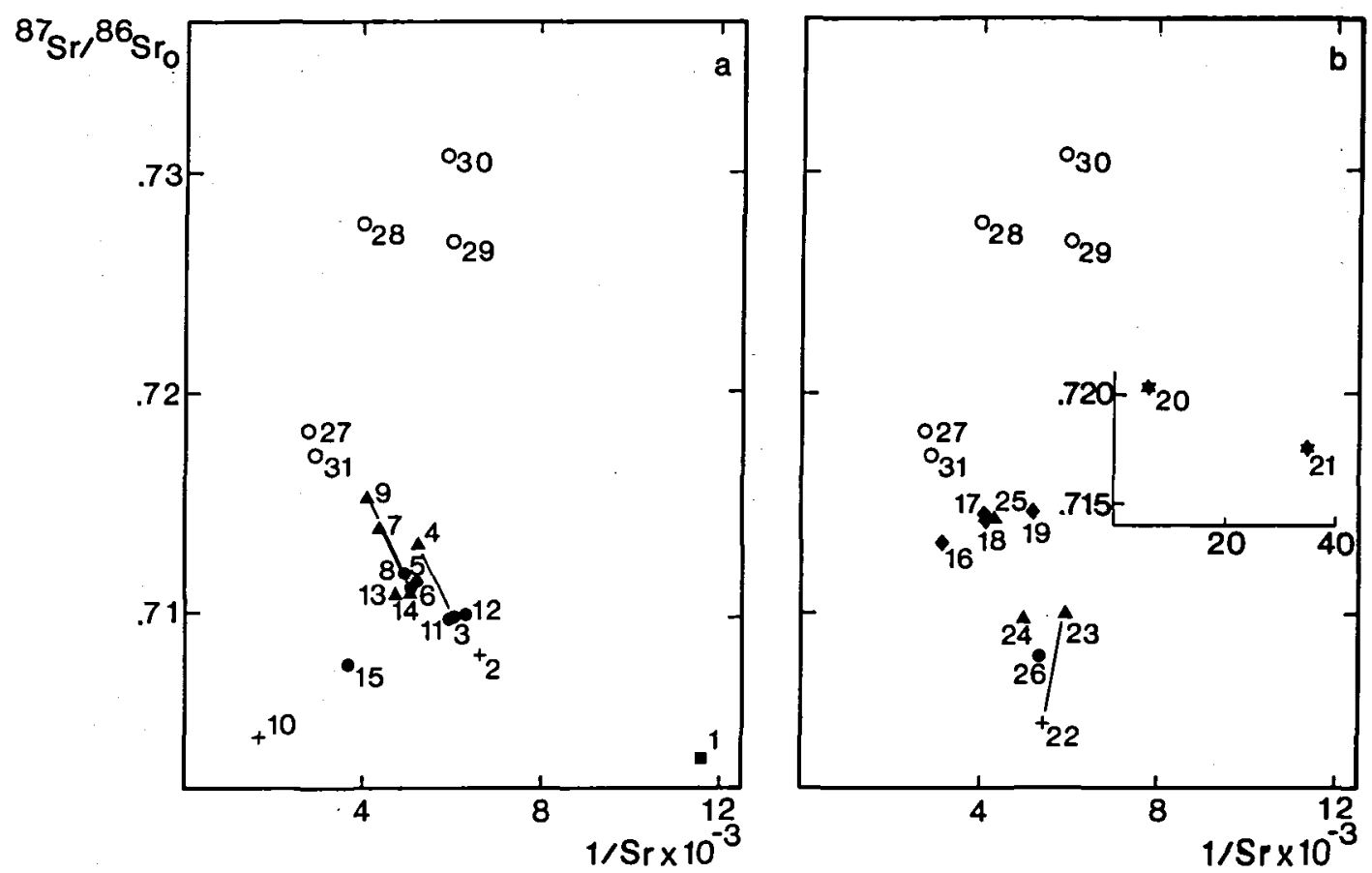

Fig. $5 .{ }^{87} \mathrm{Sr}^{86} \mathrm{Sr}_{0}$ versus $1 / \mathrm{Sr}$ mixing diagrams for samples from (a) the Vaigat Formation and (b) the Maligât Formation. Lines connect samples from composite lava flows. Symbols as in fig. 2. 


\begin{tabular}{|c|c|c|c|c|c|}
\hline \multirow{2}{*}{$\frac{\text { Table } 4}{\text { Mineral }}$} & \multicolumn{5}{|c|}{ Mineral/melt partition coefficients of $\mathrm{Sr}$ in basaltic to rhyolitic rocks } \\
\hline & Basalt & Andesite & Dacite & & Rhyolite \\
\hline Olivine & $0.003^{1}$ & $\leq 0.01^{2}$ & & & \\
\hline $\begin{array}{l}\text { Orthopyroxene } \\
\text { or pigeonite }\end{array}$ & $0.018^{3}$ & $0.01-0.04^{4,5}$ & 0.0085 & _ & $0.05^{6}$ \\
\hline Augite & $0.17^{7}$ & $0.093^{4}$ & & - & 0.03 \\
\hline Plagioclase & $1.5-2.2^{7}$ & $1.3-3.2^{2}$ & $2.8-6.7^{4,8}$ & & $4.4-11.5^{5,6}$ \\
\hline Sanidine & & & & & $3.8-28^{9,10}$ \\
\hline
\end{tabular}

The table shows typical partition coefficients and some ranges. Sources: 1: McKay \& Weill (1977), 2: Gill (1978), 3: Weill \& McKay (1975), 4: Philpotts \& Schnetzler (1970), 5: Ewart \& Taylor (1969), 6: Nagasawa \& Schnetzler (1971), 7: Sun et al. (1974), 8: Schock (1977), 9: Nagasawa (1971), 10: Leeman \& Phelps (1981).

1985b and Table 1 nos 11 to 15, Table 2 nos 12 and 13 and Table 3 nos 11 to 15 ). With the most tightly constrained parents, namely picritic basalts, these rocks also offer the best opportunity to constrain the contaminants. For samples 11 and 12 the estimated parent is a picrite with $\mathrm{MgO} \geq$ $18 \mathrm{wt} . \%$ and $\mathrm{Sr} \leq 100 \mathrm{ppm}$, while for sample 13 and 14 it was a picrite with $\mathrm{MgO}>14 \%$ and $\mathrm{Sr} \leq$ $120 \mathrm{ppm}$. For sample 15 a parental basalt with $\mathrm{MgO}<10 \mathrm{wt} . \%$ and $\mathrm{Sr}>160 \mathrm{ppm}$ is indicated. Further the reduced nature of all the contaminated rocks prior to the eruption $\left(\mathrm{fO}_{2}\right.$ is several orders of magnitude below quenched uncontaminated picritic rocks) and the sulphide fractionated character of the basalts together with the occurrence of scattered sandstone xenoliths point

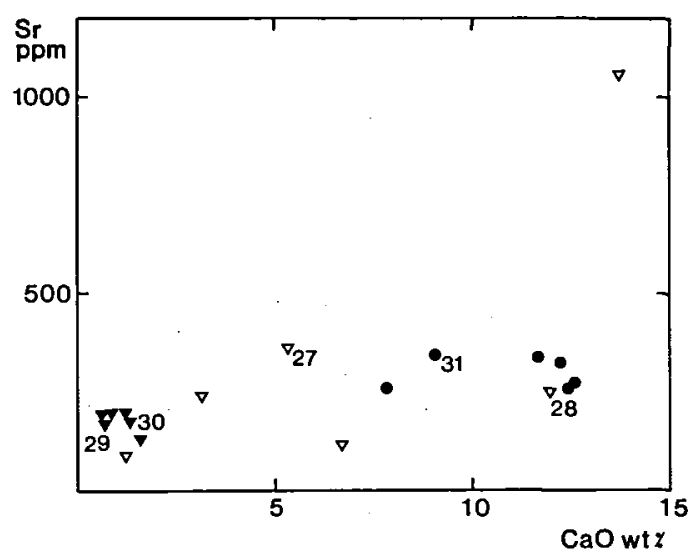

Fig. 6. Sr versus $\mathrm{CaO}$ in sediments and sedimentary xenoliths from Disko and Nûgssuaq. Note the substantial scatter shown by the sandstones and siltstones. Symbols: Filled triangles $=$ shale and shale buchite xenoliths; dots = magma modified shale xenoliths (graphite-rich plagioclase - spinel rocks); open triangles $=$ sandstones and siltstones and their equivalent buchite xenoliths. Numbers refer to analysed samples in Tables 1 and 3. Note that $\mathrm{CaO}$ increases markedly and $\mathrm{Sr}$ moderately when shale reacts with the magma. to a sedimentary contaminant carrying potentially reducing organic components (Pedersen, 1985b).

AFC calculations: picritic parent, samples 11 to 14 , shale contaminant

Calculations (Table 5) demonstrate that it is not possible to assign any mixing nor AFC curves to the data points. This is interpreted as clear evidence that shale was not a significant contaminant when the Kûgánguaq Member rocks formed.

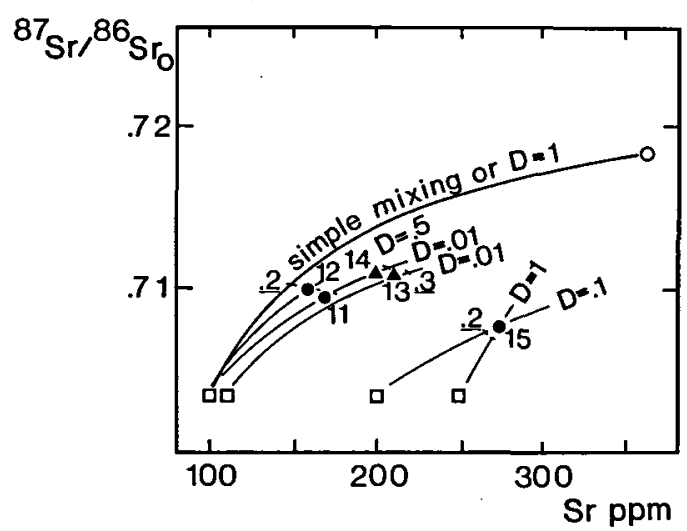

Fig. 7. ${ }^{87} \mathrm{Sr}^{86} \mathrm{Sr}_{0}$ versus $\mathrm{Sr}$ (Assimilation-Fractional-Crystallization calculation) diagram for samples from the Kûgánguaq Member in the Vaigat Formation reacting with a sandstone contaminant. For this and the following diagrams the following assumption is applied: the assimilation rate $\left(\dot{M}_{a}\right)$ equals the crystallization rate $\left(\dot{M}_{c}\right)$ or $r=\dot{M}_{a} / \dot{M}_{c}=1$ (De Paolo, 1981). Open squares $=$ parental magma and open circle $=$ model contaminant. Other symbols as in fig. 2 . The heavy line shows the AFC line for the special case when the bulk partition coefficient $D=1$. This line is analogous to a simple mixing line. The thin curves show AFC mixing trends with different D values as indicated. The underlined decimals on the AFC curves are the ratio between the mass of assimilated material and the total mass of magma $\left(M_{\mathrm{a}} / \mathrm{M}_{\mathrm{m}}\right)$. 

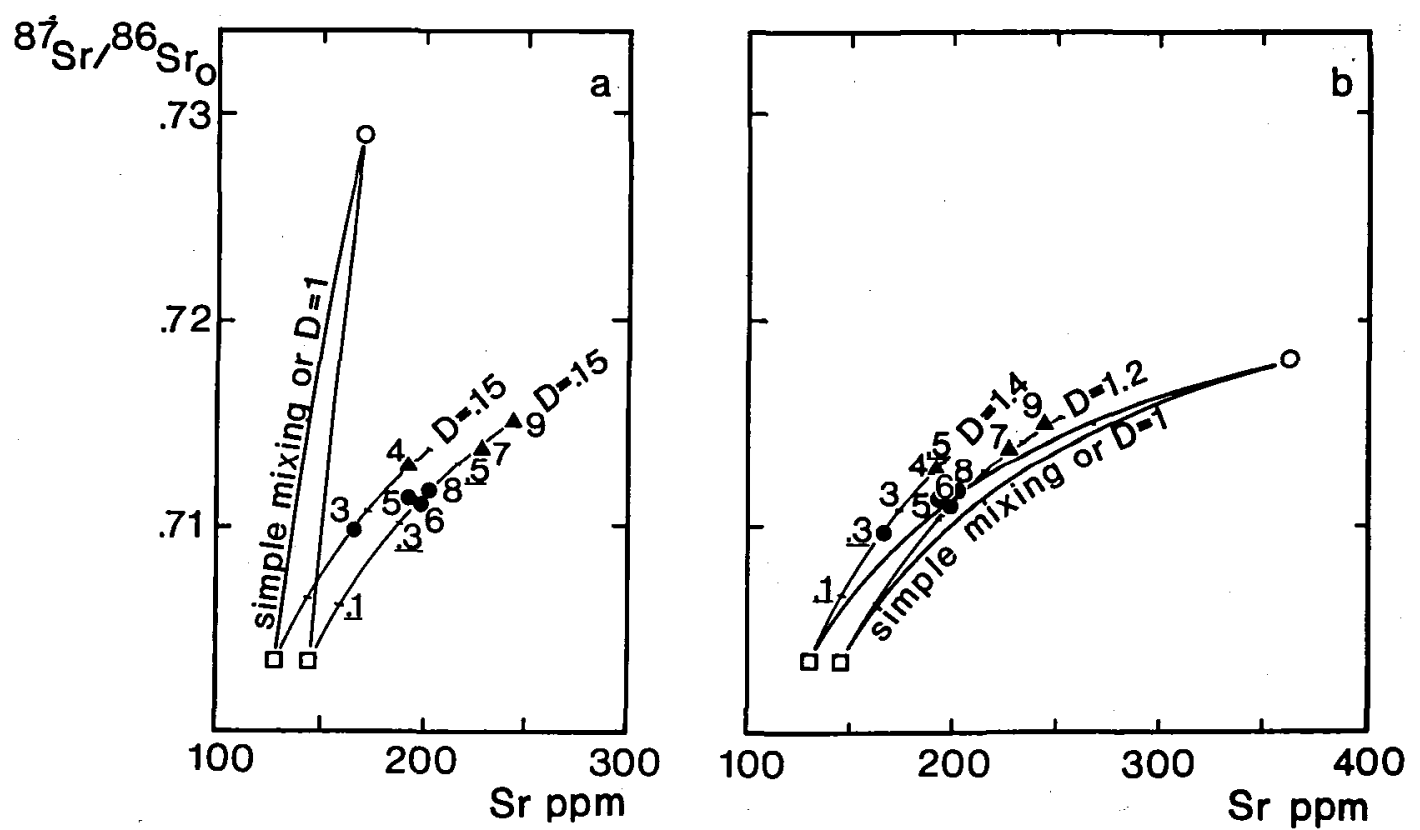

Fig. 8. ${ }^{87} \mathrm{Sr}^{86}{ }^{86} r_{0}$ versus $\mathrm{Sr}$ (AFC calculation) diagrams for samples from the Asuk Member in the Vaigat Formation for reaction with the model shale contaminant (a) and the model sandstone contaminant (b) for condition $r=1$. Note that sample pair 3 and 4 from a composite lava flow fall on a different AFC curve compared to the two sample pairs (6 and 7) and (8 and 9) from two composite lava flows which approximate a single curve.

AFC calculations: picritic parent, samples 11 to 14 , sandstone contaminant

The calculations (Table 5 and fig. 7) demonstrate that a solution can be obtained for this model. A very low $D^{\mathrm{Sr}}(0.01)$ is indicated from the calculations for samples 11,13 and 14 whereas a higher value $(0.5)$ is indicated for sample 12 . The ratio between the mass of assimilant and the mass of magma $\left(\mathrm{M}_{\mathrm{a}} / \mathrm{M}_{\mathrm{m}}\right)$ is 0.2 for the silicic basalts 11 and 12 and 0.3 for the magnesian andesites 13 and 14 . The extremely low $D^{\text {Sr }}$ values for samples 11,13 and 14 would implicate a dominance of olivine and orthopyroxene among the fractioning phases (Table 4). The observation that some olivine precipitation occurs at the initiation of sediment-magma interaction in some intrusions on Disko (unpublished and Ulff-Møller, 1977) could be invoked here in support of the model for the Kûgánguaq Member rocks, which carry olivine and orthopyroxene as the early phenocrysts (Pedersen, 1985b). Other data, however, exclude a prolonged olivine or orthopyroxene fractionation. The substantial scatter of Sr concentrations in Disko sand and siltstones (fig. 6) makes a more quantified modelling unrealistic. Qualitatively a lower Sr content in the sandstone contaminant (at similar $\mathrm{Sr}$ isotope ratio) yields a similar model $\mathrm{D}^{\text {Sr }}$ value but increases the degree of contamination. A model which implicates a $D^{\mathrm{Sr}}<0.01$ should be considered geologically unrealistic.

Since almost all Mesozoic to early Tertiary sandstone sequences in the area contain subordinate layers of shale or siltstone (Henderson et al., 1976), and since plagioclase precipitation would be expected by equilibration at magma-sediment contacts at such shale layers (Melson \& Switzer, 1966; Pedersen, 1979a) a model with $\mathrm{D}^{\mathrm{Sr}}>0.01$ (say 0.05 to 0.5 ) would be preferable.

A higher $\mathrm{D}^{\mathrm{Sr}}$ value would be obtained using a slightly higher Sr-concentration in the parental material in the calculation.

AFC calculations: basaltic parent, sample 15 , sandstone contaminant

Model calculations with sandstone contaminant (Table 5 and fig. 7) were performed with parental $\mathrm{Sr}=200$ and $250 \mathrm{ppm}$ respectively. The corresponding $D^{S r}$ values are 0.01 and 1 . The high $D^{\text {Sr }}$ is in accordance with the modus of the rock (Pedersen, 1985b, Table 1), where the amount of 


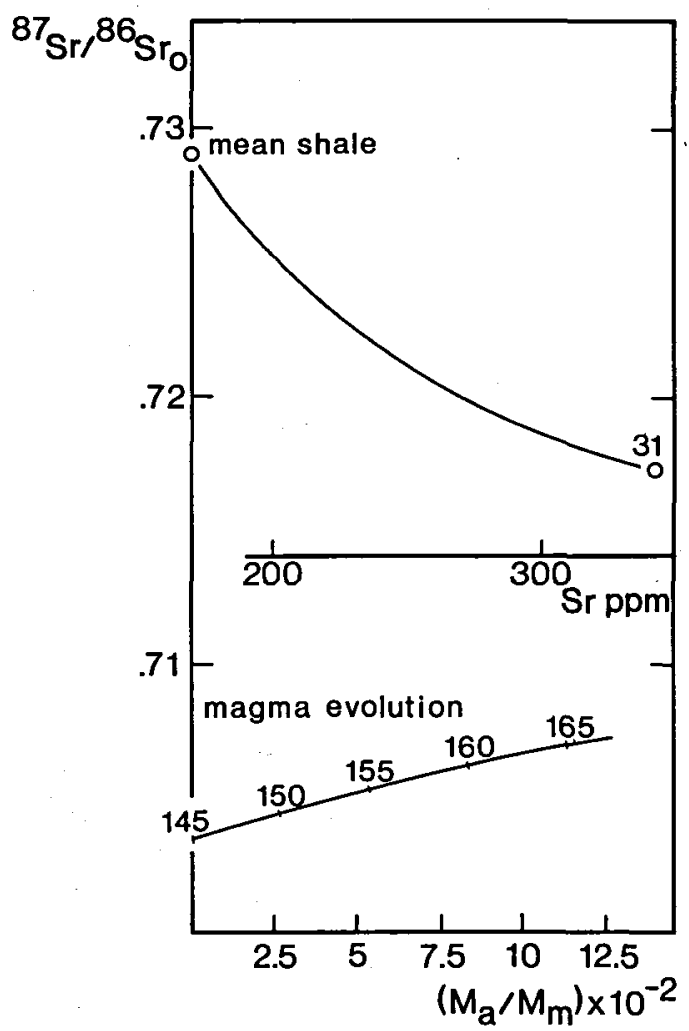

Fig. $9 .{ }^{87} \mathrm{Sr}^{186} \mathrm{Sr}_{0}$ versus $\mathrm{Sr}$ and $\mathrm{M}_{\mathrm{a}} / \mathrm{M}_{\mathrm{m}}$ diagram to illustrate the Sr isotopic evolution in a magma modified shale xenolith (31) shown in the upper part of the diagram and in the magma exemplified by the xenolith host in the Asuk Member (lower part of the diagram). The model shale is assumed as parent for the shale xenolith. The calculation assumes that the contamination rate in the xenolith has been proportional to the $\mathrm{M}_{\mathrm{a}} / \mathrm{M}_{\mathrm{m}}$ ratio in the magma. The heavy line in the middle of the figure shows the Sr concentration in the shale, while the lower curve indicates the evolution of the $\mathrm{Sr}$ concentration in the magma.

plagioclase phenocrysts by far exceeds orthopyroxene, clinopyroxene and olivine (pseudomorphs).

\section{Asuk Member}

The parents to the silicic basalts to magnesian andesites from the Asuk Member are constrained to olivine tholeiites (Pedersen, unpublished). Further, since some magnesian andesites contain up to about 2 wt.\% disseminated graphite (Pedersen, 1985a, Table 1, no. 5), and since modified shale xenoliths are widespread, substantial contributions from shale contaminants are to be expected in these unusual rocks (Pedersen, 1979a). At the same time, quartz xenocrysts, and partly dissolved sandstone xenoliths are widespread in the rocks and demonstrate that sandstone must also have contributed to the evolution of the Asuk Member rocks.

The samples 3 to 9 include silicic basalt-magnesian andesite pairs from three composite lava flows and one additional silicic basalt (no. 5). For samples 3 to 5 , a high $\mathrm{Cr}$ (ca $700 \mathrm{ppm}$ ) in the basalts compells us to assume a parental magma with $\mathrm{MgO}>13 \%$ (see Pedersen, 1985b) with $\mathrm{Sr}$ about $120 \mathrm{ppm}$. For the samples 6 to 9 with $\mathrm{Cr}=$ 350 to $400 \mathrm{ppm}$, a more evolved basaltic parent with $\mathrm{MgO}$ between 9 and $10 \mathrm{wt} . \%$ and $\mathrm{Sr}$ between 140 and $160 \mathrm{ppm}$ is indicated; this parent is exemplified by olivine-poor basalts from the Naujánguit and Qordlortorssuaq Members (see Pedersen, 1985b, Table 15).

Fig. 5a shows the Asuk Member rocks on a ${ }^{87} \mathrm{Sr} /{ }^{86} \mathrm{Sr}_{\mathrm{o}}$ versus $1 / \mathrm{Sr}$ diagrams. The lines connecting silicic basalt magnesian andesite pairs from the three composite lava flows are seen to be parallel, with the lines connecting pairs 6-7 and 8-9 being nearly concordant. This regularity is unlikely to be accidental.

AFC calculations: basaltic parents, samples 3 to 9 , shale contaminant

Results of the calculations are shown in Table 5 and fig. $8 \mathrm{a}$ and confirm that sample pair $3-4$ had a more primitive parent (128 ppm Sr) than the pairs $6-7$ and 8-9 (146 ppm Sr). The AFC solutions all require $D^{\text {Sr }}=0.15$. The calculations confirm that samples 3 and 4, and samples 6 to 9 represent separate sediment-magma reaction events, and that samples 6 to 9 could have been derived from the same contaminated magma chamber, although the set pair 8 and 9 are more evolved than 6 and 7 .

The low $D^{\mathrm{Sr}}(0.15)$ severely constrains the modal proportions of the crystallizing phases. With olivine and orthopyroxene as the only important silicate phenocryst phases observed, both of which are characterized by $\mathrm{D}^{\mathrm{Sr}}<0.05$, another phase with $\mathrm{D}^{\mathrm{Sr}}>0.15$ must be present. This phase was probably plagioclase formed through magma-shale reaction (Melson \& Switzer, 1966; Pedersen, 1979b, see also the effect on the Ca and Sr diagram, fig. 6). $\mathrm{D}_{\text {plag }}^{\mathrm{Sr}}$ is in the order of 1.5 to 2 for parental magma compositions between $1200^{\circ}$ and $1150^{\circ} \mathrm{C}$ (Sun et al., 1974) and will in- 

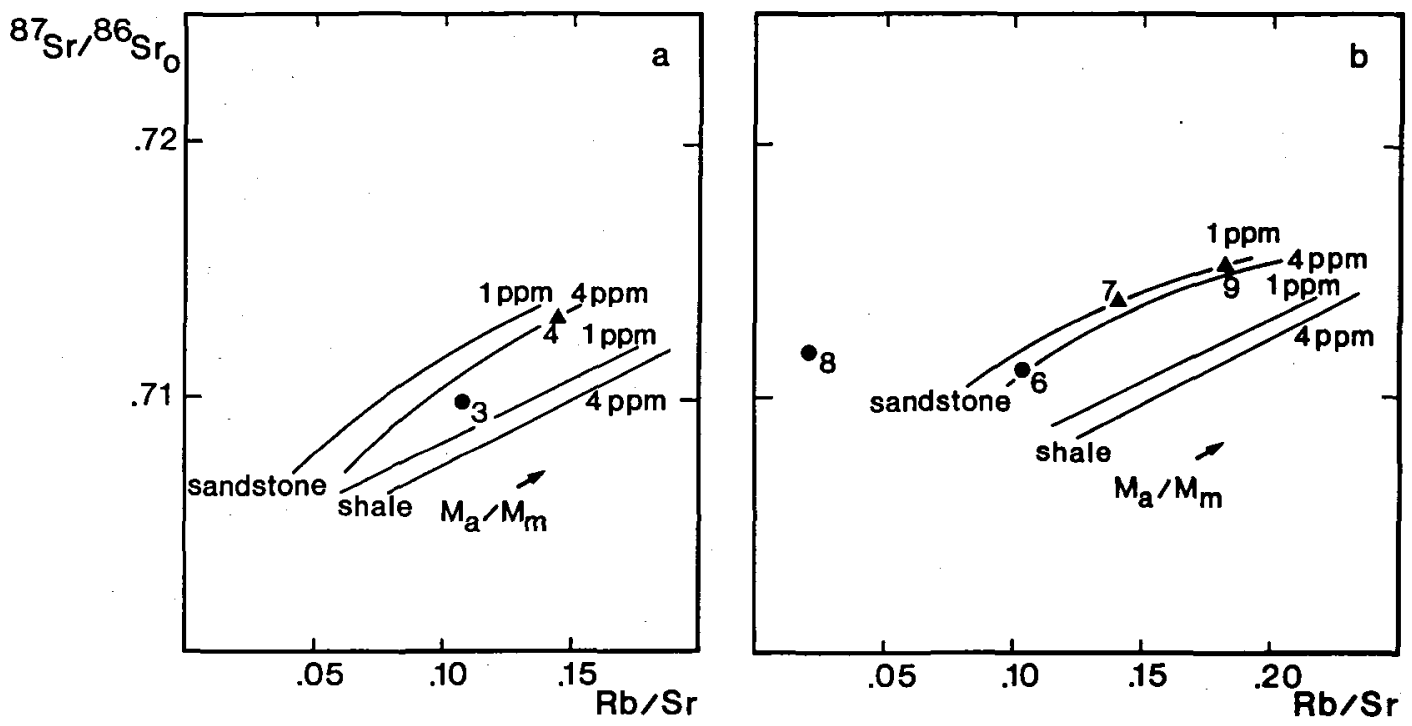

Fig. 10. ${ }^{87} \mathrm{Sr}^{86} \mathrm{Sr}_{0}$ versus $\mathrm{Rb} / \mathrm{Sr}$ diagrams for samples analysed from the Asuk Member illustrate the evolution of the $\mathrm{Rb} / \mathrm{Sr}$ ratio in the magma with increasing contamination $\left(M_{2} / M_{m}\right.$ ratio) for the condition $\left(\dot{M}_{a}=M_{c}\right)$ in the oldest composite lava flow (a), samples $3+4$ and in the two younger composite lava flows (b), samples 6 and 7,8 and 9. The trends indicate an evolution from parental magmas with 1 and $4 \mathrm{ppm} \mathrm{Rb}$. The Rb concentrations in the model shale and sandstone are 85 and $50 \mathrm{ppm}$ respectively, The $D_{S \mathrm{r}}$ values are obtained from fig. 8 .

crease with falling temperature and magma evolution (e.g. Drake \& Weill, 1975).

The plagioclase equilibration effect is tested on sample 31 - a shale xenolith from the lava flow represented by sample pair nos 6 and 7 , which reacted with the magma to form a plagioclasespinel-graphite rock. Fig. 9 shows the net $\mathrm{Sr}$ isotopic evolution in the parental magma compared to the Sr isotopic evolution in the magma modified shale xenolith. The Sr evolution path in fig. 9 may be considered as the result of a combination of two processes: 1) migration of $\mathrm{Sr}$ out of the shale and 2) formation of plagioclase at the rim.

The calculations indicate that the xenolith acquired its present $\mathrm{Sr}$ composition while reacting with an evolving magma which was isotopically not far from the parental composition, i.e. with a very low $M_{a} / M_{m}$ ratio ranging from zero to 0.125 corresponding to a $\mathrm{Sr}$ isotope ratio in the magma varying from 0.7035 to 0.7072 . The calculations were carried out on the assumption that the contamination rate in the shale xenolith was proportional to the $M_{a} / M_{m}$ ratio in the magma.

The model calculations indicate between 20 and $40 \%$ contamination in the basalts and between 40 and $70 \%$ contamination in the magnesian andesites. It is important to note that transi- tion element data demonstrate (Table 2 and unpublished data) that basalt-magnesian andesite pairs are not the results of progressive AFC evolution acting on the same magma bodies, but must represent different evolutions of a common parent.

AFC calculations: basaltic parents, samples 3 to 9, sandstone contaminant

Results of the calculations are shown in Table 5 and fig. $8 \mathrm{~b}$.

For the composite lava flow representing samples 3 and $4 D^{\mathrm{Sr}}=1.4$ while a value of $D^{\mathrm{Sr}}=1.2$ is indicated for samples 6 to 9 . Such high $D$ values would implicate substantial plagioclase precipitation in the sandstone-magma contact zones but this has not been observed in the Asuk Member rocks.

In summary, (for the two examples) both shale and sandstone contamination can be modelled, but in practice it is almost certainly a mixture of both with shales being the larger contributor.

\section{Rubidium in the Asuk Member rocks}

The $\mathrm{Rb}$ evolution is illustrated for both shale and sandstone contamination in a ${ }^{87} \mathrm{Sr}^{86} \mathrm{Sr}_{0}$ versus $\mathrm{Rb} / \mathrm{Sr}$ diagram (fig. 10a and $\mathrm{b}$ ). $\mathrm{Rb}$ concentra- 

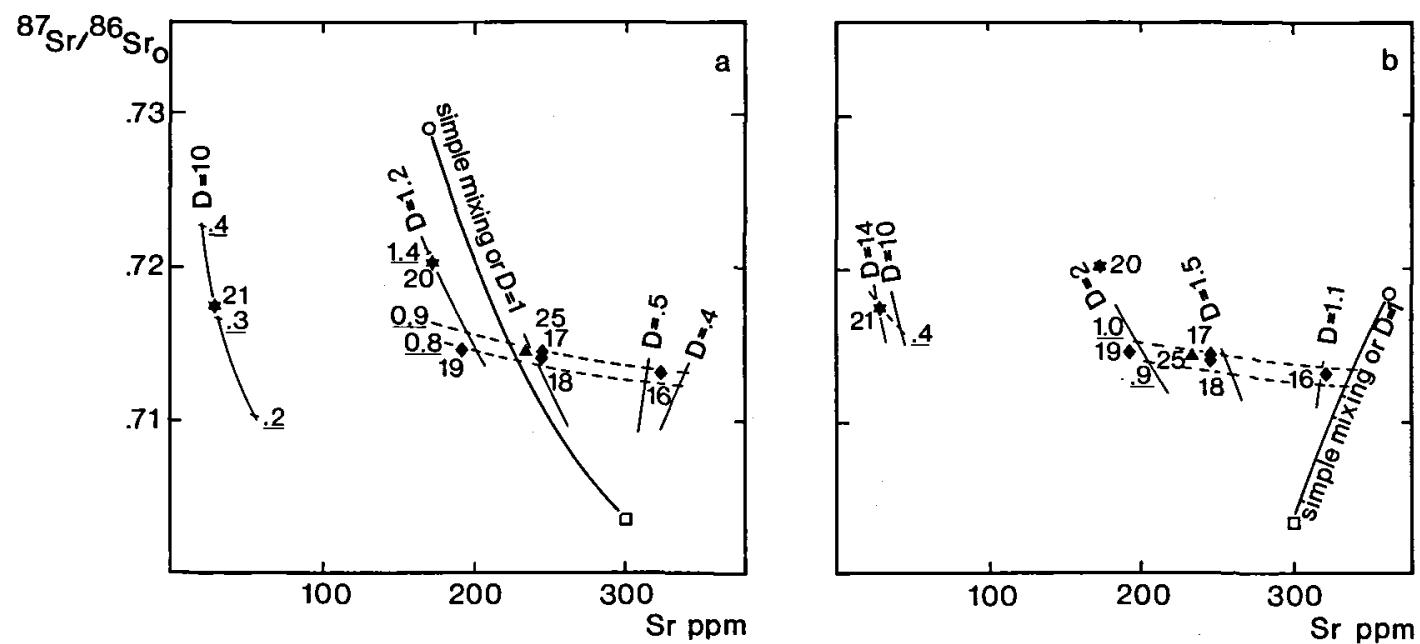

Fig. 11. ${ }^{87} \mathrm{Sr} /{ }^{86} \mathrm{Sr}_{0}$ versus $\mathrm{Sr}$ (AFC calculation) diagrams for samples from the Nordfjord Member in the Maligât Formation with model shale (a) and model sandstone (b) contaminants for the condition $r=1$. Symbols as in figs 2 and 7 .

tions in the parental magma are estimated to be in the order of 1 to $4 \mathrm{ppm}$. A Rb concentration of $85 \mathrm{ppm}$ is assumed in the contaminating shale, while $50 \mathrm{ppm}$ is assigned to the sandstone. As is evident from fig. $10 a$ and $b$, none of the model calculations give well-defined fits, but the sandstone contaminant gives better apparent fits than the shale contaminant. The distinct differences in $\mathrm{Rb}$ in the basalts could represent a substantial inhomogeneity in $\mathrm{Rb}$ in the magma chambers. However, we prefer the alternative that $\mathrm{Rb}$ has been remobilized by mild zeolite facies metamorphism affecting in particular the $\mathrm{Rb}$ concentration in some basalts.

\section{Silica-enriched rocks from the Maligât} Formation

The samples from the Nordfjord Member (no. 16 to 21 ) include four dacites (16 to 19) and two rhyolites (20 and 21). The xenolith-rich andesite (25) from the Niaqussat Member is included with the Nordfjord Member data because of its chemical and petrographical relations to these rocks (Pedersen, 1981).

\section{The dacites from the Nordfjord Member}

The low concentration of $\mathrm{Cr}$, and high $\mathrm{Ti}$ and $\mathrm{P}$ points to an evolved basaltic parent with $\mathrm{MgO}<$ $6 \%$ and $\mathrm{Sr}$ around $300 \mathrm{ppm}$ for the least silicic rocks, in accordance with the composition of the basaltic rocks occurring in the Nordfjord Member (Pedersen, 1977b and unpublished data).
The dacites carry plagioclase as the dominant phenocryst phase (e.g. Pedersen, 1981) and some rocks contain abundant xenoliths of modified shale and sandstone. In contrast to sedimentary xenoliths carried by the contaminated volcanic rocks from the Vaigat Formation with their more $\mathrm{MgO}$-rich and hence hotter parental magmas, the sedimentary xenoliths in the dacites are commonly rimmed by plagioclase and orthopyroxene, and cognate inclusions of norite are common. This demonstrates that marked crystallization of silicate phenocrysts accompanied the contamination process (Pedersen, 1981).

AFC calculations: basaltic parents, samples 16 to 19 and 25 , shale contaminant

The results of the calculations are shown in Table 5 and fig. 11a. Samples 17,18 and 25 can be modelled to fit an AFC curve for $\mathrm{D}^{\mathrm{Sr}}=$ ca 0.9 , while the most silicic dacite (sample 19) fits a curve for $D^{S_{r}}=1.3$. For one sample (16) a distinctly lower $D^{\text {Sr }}$ value $(0.4-0.5)$ must be used in the calculations. If the observed silicate phenocrysts in the dacites are used as a first approximation to the solid precipitate (although they only represent the late stage crystallization), then about 60 to 70 vol. \% plagioclase and $30-40 \%$ low Ca pyroxene (Pedersen, 1981) would implicate $\mathrm{D}^{\mathrm{Sr}}$ in the order of 1 to 2 (partition coefficients in Table 4). The shale model $\mathrm{D}^{\mathrm{Sr}}(0.9)$ is slightly low compared to this estimate and could be caused by lesser early stage precipitation of 
plagioclase or by mixed shale and sandstone contamination, or by a combination of these factors. The shale contamination model fits well for sample 19. The low model $D^{\mathrm{Sr}}(0.4-0.5)$ for sample 16 points to another dominant contaminant, which is probably sandstone (see below).

AFC calculations: basaltic parents, samples 16 to 19 and 25 , sandstone contaminant

The results of the calculations are shown in Table 5 and fig. 11b. With sandstone as contaminant sample 16 can now be modelled with $D^{\mathrm{Sr}}=1.1$, which is a more reasonable solution than obtained for the shale contaminant.

The dominant phenocrysts in sample 16 are plagioclase and orthopyroxene. Sample 16 is a very alkali-poor dacite (Table 2) with widespread tridymite, and it has a higher $\mathrm{Zr}$ concentration than found in any shale sample or other igneous rock on Disko, whereas much higher $\mathrm{Zr}$ is known from some sandstones (sample 27, Table 2). Altogether $\mathrm{Sr}$ isotopes and other evidence points to a dominant sandstone contamination of sample 16.

Calculations demonstrate that samples 17 to 19 and 25 can be modelled with the sandstone contaminant and with $\mathrm{D}^{\mathrm{sr}}=1.5$ to 2.0. The evidence from the sedimentary xenoliths make it unlikely that sandstone was the dominant contaminant.

\section{Rhyolites from the Nordfjord Member}

The two analysed rhyolite blocks (samples 20 and 21) are both garnet-bearing peraluminous acid rocks with graphite (Table 1 and 2); but whereas sample 20 is rich in xenocrysts and phenocrysts and shows comparatively elevated levels of $\mathrm{Ba}$, $\mathrm{Sr}$ and $\mathrm{Zr}, \mathrm{Ti}$ and $\mathrm{P}$, sample 21 is xeno- and phenocryst poor and shows depletion in these elements. The presence of strongly graphitic rhyolite tuffs in the Nordfjord Member (Pedersen, $1977 \mathrm{~b}$ and unpublished data) points to a contribution of shale contaminant to the rhyolites, and the occurrence of shale xenoliths in »sample 20 type « rhyolites points to the same. Both samples are so evolved that the nature of the basaltic parent is not immediately apparent, but the association with the dacites and the evolved Nordfjord Member basalts points to the same evolved basaltic parent as inferred for the dacites. For both rocks the presence of cognate, less evolved igneous inclusions indicate that they are cooled from a hotter magma (A. K. Pedersen, unpublished data).

AFC calculations: basaltic parent, samples 20 and 21 , shale contaminant

The results of the calculations are shown in Table 5 and fig. 11a. Sample 20 can be modelled with a shale contaminant and $D^{\mathrm{Sr}}=1.2$, and the model indicates the highest degree of contamination in any igneous rock from Disko as expressed by the $M_{a} / M_{m}$ ratio $=1.35$. The observed dominant silicate phenocrysts are plagioclase, quartz and orthopyroxene. $D_{\text {plag/iq }}^{S_{\text {r }}}$ is about 4 to 11 in such evolved rocks (Table 4), and the calculated model value is acceptable, but represents an AFC integration spanning a large range in magma composition and temperature. The calculation on sample 21 is even more extreme in this respect, and indicates $a D^{S r}=10$, while the $M_{a} / M_{m}$ ratio of 0.3 indicate a comparatively minor contribution from the contaminant in this rock.

The dominant phenocrysts in sample 21 are plagioclase, sanidine and quartz, and for plagioclase, very high $D_{\text {plag/iq }}^{\text {Sr }}$ values (about 11 ) have been reported from very evolved low temperature rhyolites (Table .4), while $D_{\text {safiq }}^{\mathrm{Sr}}$ is in the order of 4 to 28 (Table 4). The high feldspar/ liquid partition coefficients indicate that the $\mathrm{Sr}$ concentrations and $\mathrm{Sr}$ isotope compositions in the evolving rhyolite magma could be markedly affected by feldspar-equilibration effects at sediment-magma reaction zones. The calculations represent a considerable temperature and magma composition integration with considerable variation of $D^{S r}$ between low values at high temperatures and high values at low temperatures.

AFC calculations: basaltic parent, samples 20 and 21 , sandstone contaminant

The results of the calculations are shown in Table 5 and fig. $11 b$.

For sample 20 no solution can be obtained with the chosen sandstone contaminant, since the ${ }^{87} \mathrm{Sr}{ }^{86} \mathrm{Sr}$ ratio is higher than the same ratio in the contaminant. For sample 21, a solution with $\mathrm{D}^{\mathrm{Sr}}$. $=10$ to 14 and $\mathrm{M}_{\mathrm{a}} / \mathrm{M}_{\mathrm{m}}=0.4$ to 0.5 is obtained. As in the case of shale contamination, the high $\mathrm{D}^{\mathrm{Sr}}$ values are explained by the high feldspar/ 

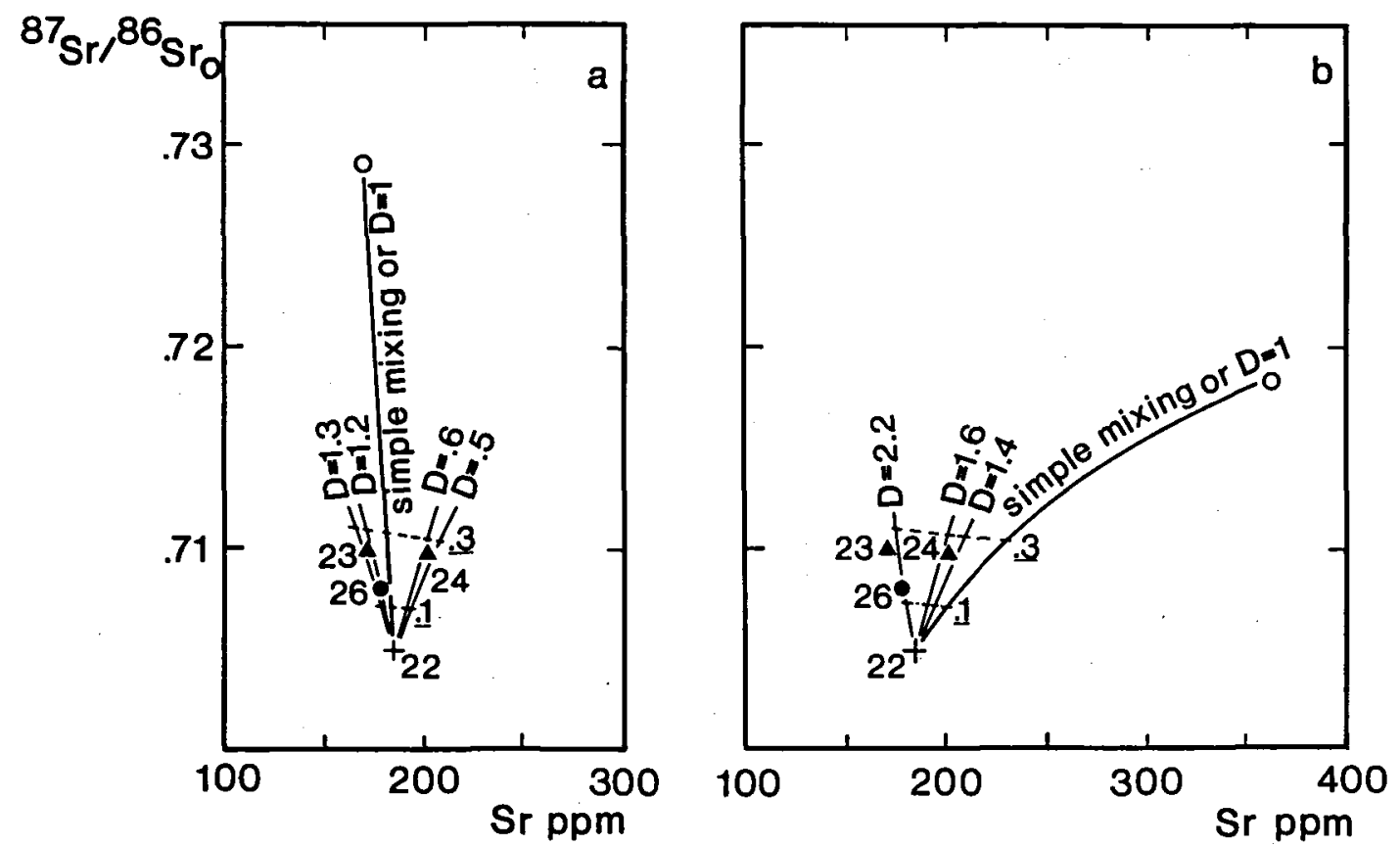

Fig. 12. ${ }^{87} \mathrm{Sr}^{86} \mathrm{Sr}_{0}$ versus $\mathrm{Sr}$ (AFC calculation) diagrams for samples from the Niaqussat Member in the Maligat Formation with model shale (a) and model sandstone (b) contaminants for the condition $r=1$. Sample 22 is selected as parental magma composition. Symbols as in figs 2 and 7.

liquid partition coefficients in evolved liquids at low temperature. The widespread presence of graphite, and the peraluminous nature of the rhyolite points to a dominant shale contaminant, but a substantial contribution from a sandstone contaminant is also likely.

The basalts to andesites from the Niaqussat Member

The samples from the Niaqussat Member include one basalt (22), one silicic basalt (26), two magnesian andesites (23 and 24) and one andesite (25), of which sample 25 has been treated together with samples 17 to 19 . Samples 22 and 23 form a composite lava flow, of which sample 22 represents an only very slightly contaminated basalt. Sample 22 has therefore been accepted as a parent for sample 23 and also for sample 26 , although this latter rock had a more magnesian parent. Only these three samples will be discussed further.
A line connecting the basalt-magnesian andesite pair on a ${ }^{87} \mathrm{Sr} /{ }^{86} \mathrm{Sr}_{0}$ versus $1 / \mathrm{Sr}$ diagram (fig. 5b) demonstrates that the $\mathrm{Sr}$ evolution is quite different for the Niaqussat Member composite lava flow as compared to the evolution in the silicic basalt magnesian andesite pairs from the three composite lava flows in the Asuk Member (fig. 5a).

AFC calculations: basaltic parent (sample 22), samples 23 and 26 , shale contaminant

The results of the calculations are shown in Table 5 and fig. 12a.

In the samples from the composite lava flow, the magnesian andesite (23) can fit an AFC curve for $D^{\mathrm{Sr}}=1.3$ (fig. 12a) and $\mathrm{M}_{\mathrm{a}} / \mathrm{M}_{\mathrm{m}}=0.25$. Cognate gabbroic inclusions of olivine, plagioclase and clinopyroxene are known from related Niaqussat Member basalts and indicate the composition of early crystals from the magma (Pedersen, 1977b). The magnesian andesite carries orthopy- 
Table 5. Summary of AFC-conditions

\begin{tabular}{|c|c|c|c|c|}
\hline Sample & $\begin{array}{l}\text { Sr in parent } \\
\text { in ppm }\end{array}$ & Contaminant & $M_{\mathbf{z}} / \mathrm{M}_{\mathrm{m}}$ & $D^{S r}$ \\
\hline $\begin{array}{l}3 \\
4 \\
5 \\
6 \\
7 \\
8 \\
9\end{array}$ & $\begin{array}{l}128 \\
128 \\
140 \\
145 \\
145 \\
145 \\
145\end{array}$ & $\begin{array}{l}\text { Sh } \\
\text { Sh } \\
\text { Sh } \\
\text { Sh } \\
\text { Sh } \\
\text { Sh } \\
\text { Sh }\end{array}$ & $\begin{array}{l}0.25 \\
0.45 \\
0.35 \\
0.35 \\
0.5-0.6 \\
0.4 \\
0.7\end{array}$ & $\begin{array}{l}0.15 \\
0.15 \\
0.15 \\
0.15 \\
0.15 \\
0.15 \\
0.15\end{array}$ \\
\hline $\begin{array}{l}3 \\
4 \\
5 \\
6 \\
7 \\
8 \\
9\end{array}$ & $\begin{array}{l}130 \\
130 \\
140 \\
145 \\
145 \\
145 \\
145\end{array}$ & $\begin{array}{l}\text { Ss } \\
\text { Ss } \\
\text { Ss } \\
\text { Ss } \\
\text { Ss } \\
\text { Ss } \\
\text { Ss }\end{array}$ & $\begin{array}{l}0.25 \\
0.45 \\
0.35 \\
0.35 \\
0.65 \\
0.40 \\
0.8-0.9\end{array}$ & $\begin{array}{l}1.4 \\
1.4 \\
1.3 \\
1.2 \\
1.2 \\
1.2 \\
1.2 \\
\end{array}$ \\
\hline $\begin{array}{l}11 \text { to } 14 \\
15\end{array}$ & $\begin{array}{l}100-110 \\
250\end{array}$ & $\begin{array}{l}\text { Sh } \\
\text { Sh }\end{array}$ & no solution & \\
\hline $\begin{array}{l}11 \\
12 \\
13 \\
14 \\
15\end{array}$ & $\begin{array}{l}100 \\
100 \\
110 \\
100 \\
250\end{array}$ & $\begin{array}{l}\text { Ss } \\
\text { Ss } \\
\text { Ss } \\
\text { Ss } \\
\text { Ss }\end{array}$ & $\begin{array}{l}0.2 \\
0.2 \\
0.3 \\
0.25-0.3 \\
0.2-0.25\end{array}$ & $\begin{array}{l}0.01 \\
0.5 \\
0.01 \\
0.01 \\
\geq 1.0\end{array}$ \\
\hline $\begin{array}{l}16 \\
17 \\
18 \\
19 \\
25\end{array}$ & $\begin{array}{l}300 \\
300 \\
300 \\
300 \\
300\end{array}$ & $\begin{array}{l}\text { Sh } \\
\text { Sh } \\
\text { Sh } \\
\text { Sh } \\
\text { Sh }\end{array}$ & $\begin{array}{l}0.97 \\
0.97 \\
0.96 \\
0.80 \\
0.95\end{array}$ & $\begin{array}{l}0.4-0.5 \\
0.9 \\
0.9 \\
1.3 \\
0.95\end{array}$ \\
\hline $\begin{array}{l}16 \\
17 \\
18 \\
19 \\
25\end{array}$ & $\begin{array}{l}300 \\
300 \\
300 \\
300 \\
300\end{array}$ & $\begin{array}{l}\text { Ss } \\
\text { Ss } \\
\text { Ss } \\
\text { Ss } \\
\text { Ss }\end{array}$ & $\begin{array}{l}0.90 \\
0.9-1.0 \\
0.95 \\
0.90 \\
0.95\end{array}$ & $\begin{array}{l}1.1 \\
1.6 \\
1.6 \\
2.1 \\
1.7\end{array}$ \\
\hline $\begin{array}{l}20 \\
21\end{array}$ & $\begin{array}{l}300 \\
300\end{array}$ & $\begin{array}{l}\text { Sh } \\
\text { Sh }\end{array}$ & $\begin{array}{l}1.35 \\
0.30\end{array}$ & $10^{1.2}$ \\
\hline $\begin{array}{l}20 \\
21\end{array}$ & $\begin{array}{l}300 \\
300\end{array}$ & $\begin{array}{l}\text { Ss } \\
\text { Ss }\end{array}$ & $\begin{array}{l}\text { no solution } \\
0.4-0.5\end{array}$ & 13 \\
\hline $\begin{array}{l}22 \\
23 \\
24 \\
26\end{array}$ & $\begin{array}{l}185 \\
185 \\
185 \\
185\end{array}$ & $\begin{array}{l}\text { Sh } \\
\text { Sh } \\
\text { Sh }\end{array}$ & $\begin{array}{l}\text { parent } \\
0.25 \\
0.25 \\
0.15\end{array}$ & $\begin{array}{l}1.3 \\
0.55 \\
1.2\end{array}$ \\
\hline $\begin{array}{l}22 \\
23 \\
24 \\
26\end{array}$ & $\begin{array}{l}185 \\
185 \\
185 \\
185\end{array}$ & $\begin{array}{l}\text { Ss } \\
\text { Ss } \\
\text { Ss }\end{array}$ & $\begin{array}{l}\text { parent } \\
0.23 \\
0.25 \\
0.13\end{array}$ & $\begin{array}{l}2.5 \\
1.5 \\
2.2\end{array}$ \\
\hline
\end{tabular}

In the AFC calculations the following assumption has been made: the ratio between the assimilation rate and the crystallization rate equals 1 , i.e. the magma mass throughout the crystallization equals the original mass of magma.

$\mathrm{M}_{\mathrm{s}} / \mathrm{M}_{\mathrm{m}}$ : The ratio between the mass of assimilant and the mass of magma.

$D^{S r}$ : The bulk weight partition coefficient for $S r$ between the crystallized phases and the liquid.

Parent conditions:

Sample 3-21 and 25: Sr concentration varying see main text; $\left({ }^{87} \mathrm{Sr} /{ }^{86} \mathrm{Sr}\right) 。 0.7035$.

For samples 3 to 15 the Sr concentration of parental compositions were estimated from the known range of picritic to olivine tholeiitic basalts from the Vaigat Formation (see Pedersen, 1985b).

For samples 16 to 21 and 25 an evolved Maligât Formation tholeiitic basalt was used as a first estimated parental composition.

Samples 23-26 (minus 25): Sample 22 with a Sr concentration of $185 \mathrm{ppm},\left({ }^{87} \mathrm{Sr} /{ }^{86} \mathrm{Sr}\right)_{0}=0.7049$.

Contaminants:

Shale (Sh): Mean of samples 29 and 30 (Table 3): Sr concentrations $170 \mathrm{ppm},\left({ }^{87} \mathrm{Sr} / 86 \mathrm{Sr}\right)_{\circ}=0.729$.

Sandstone (Ss): Sample 27 (Table 3): $\mathrm{Sr}$ concentration $362 \mathrm{ppm}\left({ }^{87} \mathrm{Sr} / 86 \mathrm{Sr}\right)_{0}=0.7183$. 
roxene and pigeonite as a scarce phenocryst phase together with plagioclase microphenocrysts. The comparatively high $D^{\mathrm{Sr}}$ would fit the early crystals found in the basalts while the scattered graphite-bearing plagioclase xenocrysts and magma modified plagioclase-rich shale xenoliths could account for the high $\mathrm{D}^{\mathrm{Sr}}$ at the stage of strong contamination.

A similar $D^{S t}$ is found for the silicic basalt (26) but the $M_{a} / M_{m}$ ratio is here distinctly lower (0.15). Again here plagioclase equilibration effects must be invoked to explain the $D^{\text {Sr }}$ in this basalt which carries olivine as the only major phenocryst phase (Pedersen, 1979b).

AFC calculations: basaltic parent (sample 22), samples 23 and 26 , sandstone contaminant

The results of the calculations are shown in Table 5 and fig. $12 a$.

The calculations demonstrate that the data can fit AFC curves with $D^{\mathrm{Sr}}=2.2$ to 2.5. For the magnesian andesite, the solution gives a higher $D^{\text {Sr }}$ than should be expected, and for the silicic basalt with olivine phenocrysts the $D^{\mathrm{Sr}}=2.2$ is considered too high (Table 5).

\section{Summary and conclusions}

The present investigation includes 25 Tertiary volcanic rocks from Disko, shown to be contaminated, and in addition one very primitive, uncontaminated or almost uncontaminated volcanic rock (picrite). Five sedimentary rocks have been analysed to represent potential contaminants.

Out of the possibly contaminated rocks only two have $\mathrm{a}^{87} \mathrm{Sr} /{ }^{86} \mathrm{Sr}$ ratio $55 \mathrm{Ma}$ ago below 0.7050 , of which one is a basalt with alkaline affinities and the other - somewhat surprisingly - is a basaltic lower contact zone in a voluminous composite lava with native iron in the central part. The remaining 23 volcanic rocks are all silica enriched compared to the tholeiitic plateau basalts of the region and all of them are distinctly contaminated by $\mathrm{Sr}$ with a higher ${ }^{87} \mathrm{Sr} /{ }^{86} \mathrm{Sr}$ ratio than found in the latter.

Mesozoic to early Tertiary shales and sandstones and strongly magma modified or disintegrated remnants of these rocks are found as xenoliths and xenocrysts in the silica-enriched volcanic rocks. Therefore selected shale and sandstone compositions have been used as model contaminants in Assimilation-Fractional-Crystallization (AFC) equations developed by De Paolo (1981, 1985). While the analysed shale samples show a very limited variation and thus appear to be compositionally well constrained, the same is unfortunately far from true for the sandstone contaminants.

AFC calculations have been carried out under the simplified assumptions that the magma was contaminated with bulk Sr with a high ${ }^{87} \mathrm{Sr} /{ }^{86} \mathrm{Sr}$ ratio and that the amount of assimilated material equals crystallized material. The $\mathrm{Sr}$ concentration in a parental magma was estimated for the studied cases by comparing regional uncontaminated volcanic rocks with the contaminated rocks in question. An important parameter in the equations is the bulk Sr crystal/liquid partition coefficients $\mathrm{D}^{\mathrm{s} r}$.

Despite a considerable uncertainty in the estimation of the parent for some of the strongly silica-enriched rocks, and despite the fact that some calculations cover an extended range in compositions, temperatures and hence $D^{\mathrm{Sr}_{\mathrm{r}}}$ values, the investigated cases demonstrate a systematic evolution. This can be most simply demonstrated by summarizing the evidence from the Kûgánguaq and Asuk Members from the Vaigat Formation and the Nordfjord Member from the Maligât Formation.

The Kûgánguaq Member provides an example of picritic magmas contaminated by reducing crustal rocks. According to the calculations the magma could very well have been contaminated with sandstone or siltstone, but definitely not with shale.

The Asuk Member provides an example of parental olivine tholeiitic basalts with about 9 to $12 \% \mathrm{MgO}$ affected by reducing crustal rocks. Calculations on three sample pairs representing three composite lava flows from the Asuk Member show that one sample pair was derived from a more primitive parent than the other two, which probably originated from a common reservoir. Both silicic basalts and magnesian andesites must have reacted with the same contaminants which were probably a shale-dominated mixture of shale and sandstone.

The Nordfjord Member samples provide an example of an evolved plagioclase-phyric basalt 
contaminated to form dacites and rhyolites. Three of the investigated dacites appear to be contaminated by a dominating shale component, probably with subordinate sandstone. One dacite shows isotopic evidence of dominant sandstone contamination, and this is confirmed by other trace element evidence.

Two rhyolite samples, associated in the field with strongly graphitic rhyolite-tuffs demonstrate a quite diverging evolution. The least evolved represents a very strongly contaminated magma, developed through the reaction with shales. The other sample has probably also reacted with shale, however it is distinctly less contaminated than the first rhyolite, but much stronger affected by crystal fractionation.

Under the given assumptions the calculations give information on $\mathrm{D}^{\mathrm{Sr}}$. In the basaltic to andesitic rocks only olivine, clinopyroxene, orthopyroxene and plagioclase have significantly contributed to $\mathrm{D}^{\mathrm{Sr}}$, while sanidine and quartz may have been of additional significance for the most evolved dacites and the rhyolites.

The calculated $D^{\mathrm{Sr}}$ values appear to be systematically lower in the Vaigat Formation than in the Maligât Formation rocks and varies with the rock types.

The Kûgánguaq Member rocks show particularly low calculated $D^{\text {sr }}$ values (except for a feldspar-phyric basalt), and this is taken as confirmatory evidence that olivine was the dominating crystallizing phase.

The Asuk Member cases also show low $\mathrm{D}^{\mathrm{Sr}}$ values, dominated by contributions from olivine and? orthopyroxene, but plagioclase must have contributed to a minor degree.

In the Nordfjord Member dacites, plagioclase is the volumetrically most important phenocryst phase, and cognate crystal precipitates of noritic composition rimming shale xenoliths are widespread. The calculated $D^{\text {Sr }}$ values are distinctly higher in the dacites as compared to Vaigat Formation rocks and are in accordance with the observed dominant plagioclase crystallization. $\mathrm{D}_{\text {plagliquid }}^{\mathrm{Sr}}$ is known to increase with decreasing temperature (Drake \& Weill, 1975), and in accordance with this $\mathrm{D}^{\mathrm{Sr}}$ is higher in the least evolved thyolite and the most evolved dacite as compared to the other dacites, and reaches its most extreme in the strongly crystal fractionated rhyolite.
In conclusion, it can be firmly established that neither acid nor intermediate Tertiary magmatic rocks on Disko evolved through closed system fractionation. The combined evidence from bulk rock chemistry, petrography and mineral chemistry all indicate that the silica-enriched rocks evolved from the reaction between basic magmas and a contaminating crust.

Acknowledgements. The $\mathrm{Sr}$ isotope analyses were carried out at the isotope laboratory at the Institute of Petrology, Copenhagen University. We are grateful for major element chemical analyses from the chemical laboratories at the Geological Survey of Greenland and for trace element analyses from J. C. Bailey at the XRF laboratory at the Institute of Petrology. R. Larsen drafted some of the figures and A. K. Brantsen typed the manuscript. We greatly appreciate the constructive criticism from N. Hald, P. M. Holm, F. Kalsbeek, L. M. Larsen and F. Ulff-Møller. The mass spectrometer and X-ray fluorescence facilities are financed by the Danish Natural Science Research Council. This paper is authorized by the Director of the $\mathrm{Ge}$ ological Survey of Greenland.

\section{Dansk sammendrag}

Sr isotopanalyser præsenteres for 26 prøver af tertiære vulkanske bjergarter fra Vaigat og Maligât Formationerne på Disko, samt for $\mathbf{5}$ prøver af potentielle sedimentare kontaminanter fra Disko og Nûgssuaq.

De vulkanske bjergarter omfatter én primitiv pikrit, 11 basalter, 8 andesitter, 4 dacitter $\operatorname{og} 2$ rhyolitter. Med undtagelse af 2 basalter er alle basaltiske til rhyolitiske bjergarter tydeligt beriget $i$ radiogen $\mathrm{Sr}$, og dette tages sammen med petrografiske observationer som vidnesbyrd om reaktion med bjergarter fra jordens skorpe.

Den vidt udbredte forekomst af xenolitter og xenokryster peger imod mesozoiske til tidligt tertixre sedimenter som de vigtigste kontaminanter, og af denne grund er en skifer og en sandsten blevet valgt som hovedkontaminanter.

Beregninger, der omfatter samtidig assimilation og fraktioneret krystallisation (AFC) viser, at mafiske silikater var de dominerende fraktionerende faser $i$ de kontaminerede bjergarter $i$ Vaigat Formationen, mens udfaldning af plagioklas spillede en dominerende rolle $\mathrm{i}$ de kontaminerede bjergarter fra Maligât Formationen.

Kûgánguaq Member i Vaigat Formationen kan ikke modelleres med en skiferkontaminant, men derimod med en sandstenskontaminant. På samme måde modelleres en dacit $\mathbf{i}$ Nordfjord Member i Maligât Formationen bedst med en sandstenskontaminant. Med hensyn til de øvrige bjergarter er der vidnesbyrd om en dominerende skiferkontaminering.

Den mest kontaminerede bjergart, der er undersøgt i dette arbejde er en rhyolit fra Nordfjord Member. Den anden undersøgte thyolit viser mindre kontaminering, men en meget udpræget feldspatfraktionering.

Ingen af de siliciumberigede bjergarter synes at være dannede ved fraktionering af et basisk ukontamineret magma i et lukket system.

\section{References}

Athavale, R. N. \& Sharma, P. V. 1975: Paleomagnetic results on early Tertiary lava flows from West Greenland and their 
bearing on the evolution of the Baffin Bay - Labrador Sea region. Can. J. Earth Sci. 12, 1-18.

Bøggild, O. B. 1953: The mineralogy of Greenland. Meddr Gronland 149(3), $442 \mathrm{pp}$.

Butler, R. F. \& Coney, P. J. 1981: A revised magnetic polarity time scale for the Paleocene and early Eocene and implications for Pacific plate motion. Geophys. Res. Lett. 8, 301304.

Carter, S. R., Evensen, N. M., Hamilton, P. J. \& O'Nions, R. K. 1979: Basalt magma sources during the opening of the North Atlantic. Nature 281, 28-30.

Clarke, D. B. 1970: Tertiary basalts of Baffin Bay: possible primary magma from the mantle. Contrib. Mineral. Petrol. $25,203-224$.

Clarke D. B. \& Pedersen, A. K. 1976: Tertiary volcanic province of West Greenland. In Escher, A. \& Watt, W. S. (eds.) Geology of Greenland, 364-385. Copenhagen: Geological Survey of Greenland.

Clarke, D. B. \& Upton, B. G. J. 1971: Tertiary basalts of Baffin Bay: field relations and tectonic setting. Can. J. Earth Sci. $8,248-258$

De Paolo, D. J. 1981: Trace element and isotopic effects of combined wallrock assimilation and fractional crystallization. Earth Planet. Sci. Lett. 53, 189-202.

De Paolo, D. J. 1985: Isotopic studies of processes in mafic magma chambers: I. The Kiglapait intrusion, Labrador. $J$. Petrol. 26, 925-951.

Drake, M. J. \& Weill, D. F. 1975: The partition of Sr, Ba, Ca $\mathrm{Y}, \mathrm{Eu}^{2+}, \mathrm{Eu}^{3+}$ and other REE between plagioclase feldspar and magmatic silicate liquid: an experimental study. Geochim. Cosmochim. Acta 39, 689-712.

Ewart, A. \& Taylor, S. R. 1969: Trace element geochemistry of the rhyolitic volcanic rocks, central North Island, New Zealand. Phenocryst data. Contrib. Mineral. Petrol. 22, 127-146.

Gill, J. B. 1978: Role of trace element partition coefficients in models of andesite genesis. Geochim. Cosmochim. Acta 42, 709-724.

Hald, N. \& Pedersen, A. K. 1975: Lithostratigraphy of the early Tertiary volcanic rocks of central West Greenland. Rapp. Gronlands geol. Unders. 69, 17-24.

Hansen, K. \& Pedersen, A. K. 1985: Fission track dating of lower Tertiary rhyolitic glass rocks from Disko. Rapp. Grønlands geol. Unders., 125, 28-30.

Heinrich, K. F. J. 1966: X-ray absorption uncertainty. In McKinley, T. D., Heinrich, K. F. J. \& Wittry, D. B. (eds.) The electron microprobe, 296-377. New York: John Wiley \& Sons.

Henderson, G., Rosenkrantz, A. \& Schiener, E. J. 1976: Cretaceous - Tertiary sedimentary rocks of West Greenland. In Escher, A. \& Watt, W. S. (eds.) Geology of Greenland, 340-362. Copenhagen: Geological Survey of Greenland.

Henderson, G., Schiener, E. J., Risum, J. B., Croxton, C. A. \& Andersen, B. B. 1981: The West Greenland Basin. Mem. Can. Soc. Petrol. Geol. 7, 399-428.

Leeman, W. P. \& Phelps, D. W. 1981: Partitioning of rare earths and other trace elements between sanidine and coexisting volcanic glass. J. Geophys. Res. 86, 1019310199.

McKay, G. A. \& Weill, D. F. 1977: Kreep petrogenesis revisited. Proc. Eighth Lunar Sci. Conf. 2339-2355.

Melson, W. G. \& Switzer, G. 1966: Plagioclase-spinel-graphite xenoliths in metallic iron-bearing basalt, Disko Island, Greenland. Amer. Miner. 51, 664-676.

Nagasawa, H. 1971: Partitioning of $\mathrm{Eu}$ and $\mathrm{Sr}$ between coexist- ing plagioclase and K-feldspar. Earth Planet. Sci. Lett. 13, 139-144.

Nagasawa, H. \& Schnetzler, C. C. 1971: Partitioning of rare earth; alkali and alkaline earth elements between phenocrysts and acidic igneous magma. Geochim. Cosmochim. Acta 35, 953-968.

O'Nions, R. K. \& Clarke, D. B. 1972: Comparative trace element geochemistry of Tertiary basalts from Baffin Bay. Earth Planet. Sci. Lett. 15, 436-446.

Pedersen, A. K. 1975a: New mapping in north-western Disko, 1972. Rapp. Gronlands geol. Unders. 69, 25-32.

Pedersen, A. K. 1975b: New investigations of the native ironbearing volcanic rocks of Disko, central West Greenland. Rapp. Gronlands geol. Unders. 75, 48-51.

Pedersen, A. K. 1977a: Tertiary volcanic geology of the Mellemfjord area, south-west Disko. Rapp. Gronlands geol. Unders. 81, 35-51.

Pedersen, A. K. 1977b: Iron-bearing and related volcanic rocks in the area between Gieseckes Dal and Hammers Dal, north-west Disko. Rapp. Grønlands geol. Unders. 81, 4-14.

Pedersen, A. K. 1979a: Basaltic glass with high-temperature equilibrated immiscible sulphide bodies with native iron from Disko, central West Greenland. Contrib. Mineral. Petrol. 69, 397-407.

Pedersen, A. K. 1979b: A shale buchite xenolith with Alarmalcolite and native iron in a lava from Asuk, Disko, central West Greenland. Contrib. Mineral. Petrol. 69 , 83-94.

Pedersen, A. K. 1981: Armalcolite-bearing Fe-Ti oxide assemblages in graphite-equilibrated salic volcanic rocks with native iron from Disko, central West Greenland. Contrib. Mineral. Petrol. 77, 307-324.

Pedersen, A. K. 1985a: Lithostratigraphy of the Tertiary Vaigat Formation on Disko, central West Greenland. Rapp. Grønlands geol. Unders. 124, $30 \mathrm{pp}$.

Pedersen, A. K. 1985b: Reaction between picrite magma and continental crust; early Tertiary silicic basalts and magnesian andesites from Disko, West Greenland. Bull. Grønlands geol. Unders. 152, $126 \mathrm{pp}$.

Philpotts, J. A. \& Schnetzler, C. C. 1970: Phenocryst-matrix partition coefficients for $\mathrm{K}, \mathrm{Rb}, \mathrm{Sr}$ and $\mathrm{Ba}$, with applications to anorthosite and basalt genesis. Geochim. Cosmochim. Acta 34, 307-322.

Schock, H. H. 1977: Trace element partitioning between phenocrysts of plagioclase, pyroxenes and magnetite and the host pyroclastic matrix. J. Radioanal. Chem. 38, 327-340.

Steenstrup, K. J. V. 1883: Om Forekomsten af Nikkeljern med Widmannstättenske Figurer i Basalten i Nordgrønland. Meddr Grønland 4, 113-132.

Steenstrup, K. J. V. 1900: Beretning om en Undersøgelsesrejse til Øen Disko i sommeren 1898. Meddr Grønland 24, 249 306.

Sun, C.-O., Williams, R. J. \& Sun, S.-S. 1974: Distribution coefficients of $\mathrm{Eu}$ and $\mathrm{Sr}$ for plagioclase-liquid and clinopyroxene-liquid equilibria in ocean ridge basalt: an experimental study. Geochim. Cosmochim. Acta 38, 1415-1433.

Ulff-Møller, F. 1977: Native iron-bearing intrusions of the Hammers Dal Complex, north-west Disko. Rapp. Grønlands geol. Unders. 81, 15-33.

Weill, D. F. \& McKay, G. A. 1975: The partitioning of Mg, Fe, $\mathrm{Sr}, \mathrm{Ce}, \mathrm{Sm}, \mathrm{Eu}$ and $\mathrm{Yb}$ in lunar igneous systems and $\mathrm{a}$ possible origin of KREEP by equilibrium partial melting. Proc. Sixth Lunar Sci. Conf. 1143-1158. 